\title{
THE IMPLICATIONS OF ENTRENCHING PROPERTY RIGHTS IN SECTION 7 OF THE CHARTER OF RIGHTS
}

\author{
JEAN McBEAN, Q.C.*
}

\begin{abstract}
The author discusses the legal implications of entrenching property rights into s. 7 of the Charter. She outlines the legislative history of s. 7 and outlines the nature of the s. 7 review process. Some of the laws which may be affected by entrenching property rights are examined and a possible solution is offered to this dilemma.
\end{abstract}

\section{INTRODUCTION}

In April of 1982 Canada entrenched into its Constitution the Charter of Rights and Freedoms.' Section 7 of the Charter reads as follows:

Everyone has the right to life, liberty, and security of the person and the right not to be deprived thereof except in accordance with the principles of fundamental justice.

The predecessor to this section is s. (1)(a) of the Canadian Bill of Rights which provides: ${ }^{2}$
It is hereby recognized and declared that in Canada there have existed and shall continue to exist without discrimination by reason of race, national origin, colour, religion or sex, the following human rights and fundamental freedoms, namely, (a) the right of the individual to life, liberty, security of the person and enjoyment of property, and the right not to be deprived thereof except by due process of law. [Emphasis added]

Although the federal Liberal government originally proposed that $\mathrm{s.} 7$ also include the enjoyment or property as a protected right, provincial opposition convinced it to remove that phrase, and the present wording is identical to that which was proposed by the federal government in the Constitutional Resolution proposed in October $1980 .{ }^{3}$ Since that Resolution was introduced there have been legislative attempts, both before and after the enactment of the Charter, to amend s. 7 to add property as a protected category. Moreover, there have been attempts by various litigants to attain in effect a "judicial amendment" to the section by importing a wide meaning to the terms "liberty" and "security of the person" to encompass economic rights. The potential effects of adding property to s. 7 are the concern of this article.

Depending on the definition of property that is adopted, the entrenchment of property rights in $\mathrm{s.7}$ can have two possible consequences. In the first instance, if the traditional definition of property is utilized by the courts, it might simply act as a protection against the unfair deprivation of property in its traditional sense from property owners. In this case, the section would have positive effects for property owners, but would be generally irrelevant to the propertyless class of Canadians, although in some cases it might actually have a negative impact. An example of such a negative effect would be if an amended s. 7 were the means of preventing a propertyless individual from successfully asserting some right, such as a wife claiming a share of matrimonial property under one of the provincial

- McBean, Becker, Cochard \& Gordon, Barristers and Solicitors, Edmonton, Alberta.

1. Constitution Act, 1982, as enacted by the Canada Act, 1982 (U.K.), c. 11 [Hereinafter the Charter].

2. R.S.C. 1970, App. III.

3. See, the testimony of Minister of Justice Chretien before the Special Joint Committee on the Constitution of Canada Proceedings, Issue 45 (January 26, 1981). 
matrimonial property laws. Moreover, as is surmised in the final part of this article, the entrenchment of property could affect negatively environmental, land utilization, social welfare, labour and other socially useful laws of general benefit. For example, courts might strike down a labour law which prevented the firing of workers who join a union if it was found that such a law was a deprivation of the property of the employer. Only if the law could be upheld under s. 1 of the Charter as justifiable in a democratic society would it remain valid.

Alternatively, if the courts were to use a less traditional definition of property, the entrenchment of property rights could have very positive effects for both propertied and propertyless Canadians. This would result from an interpretation of the term "property" that included the "new" property of government benefits. This issue will be explored in the last part of the article.

To date there has been little public debate on this important and complex question of entrenching property rights in the Charter, a proposal which to some extent has been treated as a "motherhood issue", designed only to protect the corner grocery store and the family home. It has been suggested that the fact that the supporters of the amendment are largely big landowners, pit and quarry owners, and banks who wish protection from government interference with their enjoyment of property, to some extent belies this characterization. ${ }^{4}$ Certainly a major supporter is the National Citizens Coalition which in a large advertisement in the Globe and Mail in May 1983 not only advocated the introduction of property to the Charter, but also demanded that the s. 33 override provision would not be applicable to property rights. Other groups which have passed resolutions in favour of entrenching property rights include the Canadian Chamber of Commerce, the Canadian Real Estate Association, the Ontario Real Estate Association, the Canadian Institute of Planners, and the Canadian Bar Association. Opposition has been voiced by such womens' groups as the Canadian Advisory Council on the Status of Women, and some environmental groups. ${ }^{5}$

Whether this is an innocuous amendment, designed only to placate Canadian free enterprisers, or is indeed the dangerous vehicle which some perceive will take away the hard won rights of Canadian workers to occupational health and safety laws, of Canadian wives to the benefit of matrimonial property laws, and of Canadian citizens in general to the benefits of environmental laws, rent control legislation and numerous other acts of government which benefit Canadians while encroaching on the property rights of those affected by the law, turns on the issue of what notions of fairness the courts will consider as inherent in the "principles of fundamental justice". To answer that question this article will review Canadian litigation to date by examining relevant judicial decisions both on s. 7 of the Charter and of its predecessor provisions in the Canadian Bill of Rights, and compare and contrast our law on this matter with the law of other countries, particularly, the United States.

4. Symes, Brief Re Entrenchment of Property in Section 7 of the Charter, October, 1983, Documentation Centre, Canadian Advisory Committee on the Status of Women, Ottawa.

5. Hansard, House of Commons Debates, February 1, 1985, at 1935, 1940. 


\section{A. THE LEGISLATIVE HISTORY OF SECTION 7}

As stated above, the present wording of s. 7 is identical to that which was originally proposed by the federal government in October, 1980. During the Committee hearings on the Constitution, and later in the House of Commons, the Progressive Conservative opposition proposed that $\mathrm{s} .7$ be amended to include as a protected right the "enjoyment of property". Although the Liberal government indicated initially in the Committee hearings that it would support that amendment, it subsequently changed its position, and the amendment was defeated in both the Committee and later in the House. ${ }^{6}$ Throughout, Justice Minister Chretien indicated that on principle the Liberal government supported the concept of entrenching property rights, but in view of the opposition from many of the provinces, who feared for their zoning legislation and foreign ownership of land regulations, he indicated that the government would have to withdraw its support for the amendment, promising to keep the proposal as an item for the next round of discussions on the Constitution.' In addition to the opposition directly from the provinces, opposition came from the New Democratic party which opposed the amendment on the grounds that the provision would adversely affect the right of both the provincial and federal governments to engage in public ownership of resource based and other industries, and would generally render the provinces incapable of effectively legislating with respect to land utilization. At one point it appears that the leader of the New Democratic party, Ed Broadbent, threatened to withdraw support for the various constitutional measures which had been discussed and agreed on to date if the government continued to support adding property to the Charter. ${ }^{8}$ Wherever the definitive opposition came from, the net result was that $\mathrm{s} .7$ was enacted without reference to property.

However, the idea of adding property to s. 7 did not die. Since 1982 the Legislative Assemblies of both British Columbia and New Brunswick have passed resolutions asking that s. 7 be amended to include property. More recently, on November 27, 1986, the Ontario Legislature during private members' hour, by a vote of 44 to 20 , passed a similar resolution, although that resolution is not binding on the government of Ontario as it did not receive the required majority of the Legislature. Members of the federal

6. These amendments were defeated on January 27, 1981 and April 23, 1981. The political history of the enactment of s. 7 can be found by reading the Minutes of Proceedings and Evidence of the Special Joint Committee on the Constitution of Canada, Issues 44-46.

7. See, id., testimony of the Hon. J. Chretien, Issue No. 45. During that same session Lorne Nystrom, a N.D.P. M.P., read to the Committee a telegram sent to it by the Premier of Prince Edward Island, Angus MacLean, which stated the "great concern" of the Province with the proposed amendment. Prince Edward Island felt that particularly its efforts to regulate nonresident ownership of land would be jeopardized by adding property as a protected category.

8. Id. 45:30. In later speeches in the House of Commons the Progressive Conservative party continually made reference to the N.D.P. opposition, and alleged that it was this oppostion which caused the then Liberal government to change its position. See, for example, speech by Blaine Thacker, Conservative M.P., Hansard, November 19, 1974, 364. New Democrats are apparently not united on this matter however, as the B.C. New Democrats supported the B.C. resolution calling for the entrenchment of property rights in s. 7, and more recently the N.D.P. government in the Yukon has enacted human rights legislation containing a clause protecting the right to the enjoyment and disposition of property, albeit in a rather weakly worded clause. 
Progressive Conservative party, both while in opposition and in government, have introduced bills to the same effect on four different occasions. ${ }^{9}$ On several occasions members of the government, including Prime Minister Mulroney, have indicated that the matter will again be placed on the agenda for future constitutional discussions with the provinces. As a result, the meeting of Attorneys General of the provinces and the Attorney General of Canada in February 1986 established a working group to look at the implications of entrenchment. ${ }^{10}$ The method and likelihood of achieving this legislative amendment will be the next consideration.

\section{B. THE PROPOSED AMENDMENT: POLITICAL STATUS, TERMS, AND PROCEDURE FOR ENACTMENT}

The proposed amendment would add the phrase "and enjoyment of property" after the phrase "security of the person". Property would not be defined, and, therefore, might include all types of property, including not only tangible assets, such as land or chattels, but also enforceable rights. A discussion on the effects of a wide definition of property which might include the so called "new" property is found in part III $(\mathrm{H})$ of this article.

What are the reasons for putting forward the amendment? No doubt they vary. Professor Hogg stated the rationale to be as follows:"

The omission of property rights from s. 7 greatly reduces its scope. It means that 5.7 affords no guarantee of compensation or even of a fair procedure for the taking of property by government. It means that $\mathrm{s}$. 7 affords no guarantee of fair treatment by courts, tribunals or of ficials with power over the purely economic interests of individuals or corporations.

It should be noted that in order for $\mathrm{s.} 7$ to grant the protection claimed for it by adherents of an amendment depends on whether there is substantive review of legislation as in the United States, for if there is not, even adding property rights to $\mathrm{s.} 7$ will not offer a great deal more protection to those who are being unfairly deprived of their property. Moreover, in considering the necessity of such an amendment, as Professor Hogg admits, even in the absence of the Charter, the courts will imply that a fair procedure must be employed in taking property, at least unless there is an express provision to the contrary in the law..$^{12}$ Moreover, at least on the federal level, there is the Canadian Bill of Rights which guarantees the right to the enjoyment of property. At the provincial level the equivalent legislation to the Bill of Rights only exists in the Yukon, Alberta, Saskatchewan and Quebec, and of these only Alberta and the Yukon have a due process clause. ${ }^{13}$

The statements made by politicians to support the proposal are that throughout the history of civilization democracy has been based on four

9. Hansard, House of Commons Debates: 29 April, 1983 at 24997; December 6, 1984 at 979; February 1, 1985 at 1933; May 28, 1985 at 5163.

10. Hansard, House of Commons Debates: March 4, 1986 at 11191.

11. P. Hogg, Constitutional Law of Canada (1985) 746.

12. Cooper v. Board of Works for the Wandsworth District (1863) 14 C.B. (N.S.) 180, 143 E.R. 414 (Eng. C.P.).

13. Alberta Bill of Rights, 1972 S.A. c. 1 s. 1(a). The Yukon Human Rights Act was enacted in February, 1987. The survey of provincial human rights legislation was included in Tarnopolsky, "The New Canadian Charter of Rights and Freedoms as Compared and Contrasted with the American Bill of Rights" (1983) 5 Human Rights Law Quarterly 227. 
basic rights: life, liberty, security of the person and the enjoyment of private property. ${ }^{14}$ Others feel that the fundamental right to enjoyment of property dates back to the reference to property in the Magna Carta. ${ }^{15}$

How historically accurate these statements are as to the fundamental nature of property rights to democracy is questionable, and how compatible the amendment would be to the principles of the modern welfare state and modern society where the "new" property far outstrips the value of land and other traditional forms of property referred to by the politicians in their speeches is even more questionable. However, proponents of the amendment also argue that the inclusion of property as a protected right in the American Constitution prevented the sale of the seized property of the Japanese Americans during World War II, and might have better protected the seized property of Japanese Canadians during that same period, albeit it would not have protected against the actual seizure. Moreover, it is pointed out that Canada signed the Universal Declaration of Human Rights in 1948 which includes in Article 17 a right not to be arbitrarily deprived of one's property, and it is argued that the inclusion of property in s. 7 would be a way of giving effect to this right.

In order to achieve this amendment, the requirements of s. 38 of the Charter would have to be met. ${ }^{16}$ The proposed Amendment to the Constitution adopted at Meech Lake would not change these requirements. Under s. 38 in order for an amendment to take effect there must be resolutions requesting the amendment from the Senate and House of Commons, and from the legislative assemblies of at least two-thirds of the provinces which have, in aggregate, at least fifty percent of the population of all of the provinces. This means, in effect, that for an amendment to be made, either Quebec or Ontario would have to join in requesting the amendment. If any legislative assembly expressed its dissent to the enactment of the amendment by a resolution passed prior to the proclamation of the amendment, the amendment would have no effect in that province, unless and until a later resolution of the legislative assembly revoked that dissent.

In order to try to determine the likelihood of such an amendment proceeding, in January 1987 the writer contacted the federal government, the two federal opposition political parties and each provincial government to ask them what their position was in regards to the entrenchment of property rights in $\mathbf{5 . 7}$ of the Charter. ${ }^{17}$ The provincial governments of Quebec, New Brunswick and Manitoba failed to respond with their position, as did the federal Liberal official opposition. The government of

14. Brief of the Government of British Columbia on "Enshrining Property Rights in the Constitution", Appendix D, B.C. Ministry of Intergovernmental Relations Annual Report, April 1, 1985 to March 31, 1986.

15. Speech by the Honourable Jake Epp, M.P. in the House of Commons at time of first reading of the April, 1983 bill proposing the addition of property. 126 House of Commons Debates, 29 April, 1983 at 24997 . The reference to the Magna Carta has been repeated in nearly every Conservative speech in favour of the entrenchment of property rights.

16. The more stringent amending formula for certain fundamental constitutional matters is found in s. 41 .

17. The letters and position papers submitted to the writer are in her files and are available on request. 
Ontario responded, but that government has now changed, and so the response may no longer be representative of the new government's position.

Any amendment must be passed by both the House of Commons and the Senate. Svend Robinson, M.P. confirmed that the federal New Democratic party still maintains its opposition to the inclusion of property in $\mathbf{s . 7}$. In view of the lack of response of the Liberal opposition, it is not clear what stand it would take. In the past, Liberal Members of Parliament at various times have appeared to indicate support in principle, but not necessarily support when the matter comes to a vote. However, in view of the overwhelming majority of the present government, the more important position is that of the present government. The Minister of Justice, the Honourable Ray Hnatyshyn, indicated in his reply that he was sympathetic to such an amendment, a position that is consistent with the statements made by individual Progressive Conservatives, including members of the Cabinet, both in and out of Parliament, in favour of entrenchment of property rights in s. 7. However, an interesting feature of the latest statements made by members of the federal Cabinet in the House of Commons is the increased sensitivity which is being voiced that any amendment not affect matrimonial property laws. Mr. Hnatyshyn referred in his response to the joint provincial-federal working committee established by the Attorneys General. The government's final position will presumably not be determined until the committee has made its report.

Despite the likely support of the federal government, any amendment must have provincial support in accordance with s. 38 of The Constitution Act, 1982. Of the seven provincial governments which responded, only one provincial government, British Columbia, was clearly in favour of entrenchment of property rights in s. 7, and three provinces, Alberta, Prince Edward Island and Newfoundland, were definitely opposed. The responses from three provinces were neither clearly for nor against entrenchment. In view of the provisions of $s .38$ the crucial provinces will be Ontario and Quebec. The then Progressive Conservative government of Ontario indicated that it has not yet adopted a position on the advisability of a property rights amendment, and did not feel itself bound by the vote of the Legislature during Private Members' hour asking for the entrenchment of property in s. 7 because only 44 of the M.P.P.s voted in favour of the Resolution (20 voted against). In the letter on behalf of the Ontario government, reference was made to the joint provincial-federal study currently being carried out. It may be that Ontario will announce a position at the conclusion of that study. Now that Quebec is a party to the Constitution no doubt it will soon announce its position, although again it will likely await the committee report.

Some of the responses received were quite detailed. The Prince Edward Island opposition was expressed as being based on both psychological and economic reasons arising out of the history of the struggle of peasant farmers against the oppression and neglect of absentee landlords which had led the government to impose restrictions on the acquisition of land by aliens and non-resident persons or corporations. Newfoundland, in confirming its opposition at this time, gave as some of its concerns the implications such an amendment would have with respect to provincial 
jurisdiction over property rights, the inherent problems associated with the meaning of the phrase "enjoyment of property" and what that phrase would include. It was the concern for provincial jurisdiction over property rights that was emphasized by Mr. Horsman, the Minister of Intergovernmental Affairs for Alberta, who also relied on the fact that property rights were already included in the Alberta Bill of Rights. Both he and Mr. Moore, who had prepared the Prince Edward Island position paper, felt that provincial laws related to property should be dealt with in the Legislature, which could deal most sensitively to the particular needs of a province, not in the courts. Prince Edward Island suggested that if property rights were to be included in the Charter it should be in a separate section of its own, not in s. 7.

In summary, it does not appear at this time that there is sufficient political support for entrenchment of property rights to be made by legislative amendment. All six provinces whose positions have not been finalized would have to support the entrenchment of property rights, or else there would have to be changes of position by one or more of the three provinces which are presently firmly opposed. However, our recent political history would indicate that it would be dangerous to try to predict the future.

\section{THE POSSIBILITY OF ENTRENCHING PROPERTY BY "JUDICIAL AMENDMENT"}

It has been argued by a number of legal commentators ${ }^{18}$ that even without a legislative amendment to incorporate the phrase "the enjoyment of property", some, or all, forms of property rights are already protected under the terms "liberty" or "security of the person". The argument that this is the case is based largely on American jurisprudence wherein the term "liberty" appears to have received an expansive interpretation, particularly with regards to cases involving the Fourteenth amendment, as the American courts sought to selectively incorporate into matters of state jurisdiction most of the important rights and fredoms already applicable in areas of federal jurisdiction by virtue of the first eight amendments of the American Constitution. ${ }^{19}$ The result in the United States has been to interpret "liberty" not merely as providing freedom from bodily restraint, but to incorporate into one or the other of these terms, the property related concepts of freedom to contract, freedom to take up any livelihood or lawful occupation, and freedom from state action that deprives a person of all or a substantial portion of his or her capacity to earn a living.

"Security of the person" is not a term used in the American Bill of Rights, but it too has been interpreted to go beyond physical integrity and

18. See, particularly, Whyte, "Fundamental Justice" (1983) 13 Man. L.J. 455 at 473 . See also, Hogg, supra n. 11 at 744746; Manning, Rights Freedoms and the Courts (1983) 249-251; and Garant, "Fundamental Freedoms and Natural Justice" in The Charter of Rights: A Commentary, (ed. Tarnopolsky and Beaudoin), (1984) 258 at 261-5.

19. This process has been described by a number of commentators on s. 7. See, for example, Christian, "Section 7 of the Charter of Rights and Freedoms: Constraints on State Action" 22 Alta. L. Rev. 222 at 229-230, 232-234. Although, as is pointed out, there are limits to the applicability of some of the American arguments, some of the arguments in the American jurisprudence are quite persuasive. 
include the necessaries for life,$^{20}$ although jurisprudence under the European Convention on Human Rights has given the term a more restrictive meaning. ${ }^{21}$

The argument put forward in Canada is that the words used in 5.7 override both its contextual connotation and its legislative history. It is true that the debate in the Special Joint Committee of the Senate and House of Commons and later in the Commons centred on the traditional concept of property, that is, the family home or the corner grocery store. Thus, there may be room to interpret "liberty" or "security of the person" as including protection for the "new property" (a concept which is more fully discussed below in part III(H), but one that includes economic interests such as rights to welfare, public housing and other forms of government aid) without offering such protection to the "old property". However, many of the cases in which some form of protection from the deprivation of property has been claimed concerned traditional forms of property, and some of the legal commentators have argued that $\mathrm{s} .7 \mathrm{can}$ be interpreted to protect all types of property. ${ }^{2}$ Others argue that at least any state action which deprives a person of all (or a substantial portion) of his or her capacity to produce an income could be seen as a threat to the security of the person..$^{23}$ To date, there has been no attempt by the courts in $\mathrm{s} .7$ litigation to draw distinctions between the two types of property. It is the writer's view that if the Supreme Court were to find that all property rights are guaranteed under either "liberty" or "security of the person", this would amount to a form of judicial amendment.

There has been a mixed judicial response on this question of whether property is included in s. 7, with the overwhelming weight of authorities stating that property is not included. However, since the Supreme Court has not yet ruled on the matter, one cannot simply rely on the fact that the weight of the authorities is one way as definitive of the final determination of the issue.

The earliest judgment wherein it was suggested that the enjoyment of property might be included within the scope of $s .7$ was the decision of The Queen in the Right of New Brunswick v. Fisherman's Wharf Ltd. ${ }^{24}$ wherein Dickson J. found, without hearing argument from counsel on the point, that the term "security of the person" must extend to the right not to be deprived of property rights which relate to the security of the person. $\mathrm{He}$, therefore, gave this as a "corollary ground" for finding that no lien attached to certain goods seized pursuant to the New Brunswick law under review. No reference was made to any authority for this proposition, nor was there any comment on the legislative history of s. $7 .^{25}$ The decision was upheld by the New Brunswick Court of Appeal on non-Charter grounds,

20. See, the right to security in the Universal Declaration of Human Rights, 1948 cited by Wilson J. and quoted below. See also, "Medical Treatment and the Criminal Law" Working Paper No. 26, L.R.C.C. Ottawa, 1980, at 6.

21. Lee, "Section 7 of the Charter: An Overview" (1985) U. of T. Fac. L. Rev. 1 at 1-2.

22. Manning, supran. 18 at 251.

23. Whyte, supra n. 18 at 474.

24. (1982) 135 D.L.R. (3d) 307 at 315 (N.B.Q.B.).

25. The decision has been the object of sharp criticism. See particularly, Brandt, Case Comments, 61 Can. Bar Rev. 398. 
with the comment by LaForest J.A. (as he then was), that "security of property" was not expressly protected by the Charter, in order not to frustrate "regulatory schemes ... . obviously intended to reallocate right; and resources" which of necessity affect vested rights. ${ }^{26}$

Since that time there have been a number of cases where plaintiffs hav: raised the argument that either "security of the person", or more usually, "liberty" did protect against a deprivation of economic rights. The Federal Court on a number of occasions has ruled that 5.7 has no economi: content, and that property rights, such as freedom to contract, are neithe: explicitly nor implicitly protected by this section. ${ }^{27}$ Similarly, both th: Ontario Divisional Court and the Ontario Court of Appeal have on it number of occasions rejected the argument that either "liberty" 0 : "security of the person" protects economic or property rights..$^{28}$ In it number of instances the Divisional Court judgments have relied in part olı the legislative history of s. 7, which it was said made it "patently clear that s. 7 was not intended to include economic rights". ${ }^{29}$ However, mor:?

26. The Queen in the Right of New Brunswick v. Fisherman's Wharf, (Sub nom The Queen in th : Right of New Brunswick v. Estabrooks Pontiac Buick Ltd.)(1983) 144 D.L.R. (3d) 21, (19831 44 N.B.R. (2d) 201 at 214.

27. Axler v. R. Unreported, 31 May, 1982 (F.C.T.D.), a statement of claim that collection effort i employed by the Minister of National Revenue interfered with the Plaintiff's right tı property was struck out (cited in Christian, supra n. 19, and Garant, "L'Article 7 de l:t Chartre - Toujours Enigmatique Apres 18 Mois de al Jurisprudence" 13 Man. L. Rev. 47 ' at 480); Re Groupe des Eleveurs de Volailles de l'Est de l' Ontario et al and Canadian Chicke, t Marketing Agency (1984) 14 D.L.R. (4th) 151 at 181 (F.C.T.D.), a case involving chickelı production quotas and a claim that such quotas infringed on the applicants' freedom tı, contract which was alleged to be protected by "liberty"; Public Service Alliance of Canada v. The Queen in the Right of Canada (1984) 11 D.L.R. (4th) 337 at 368 (F.C.T.D.), again th : idea that liberty included the notion of freedom to contract was rejected, this time in a cas : involving the right to strike; decision affd. without reference to this part of the reasons fo: judgment, 11 D.L.R. (4th) 387 (F.C.A.); Re Downey and the Queen 14 W.C.B. 21.1 (F.C.T.D.), which found that "security of the person" does not include job security; $R$ : Horbas and Minister of Employment and Immigration (1985) 22 D.L.R. (4th) 60I (F.C.T.D.), a case not involving property rights, but in which the court again confirmed tha : the term "liberty" was restricted to bodily freedom issues; Smith Kline \& French Laborato. ries Ltd. v. A.G. of Canada (1985) 24 D.L.R. (4th) 321 at 363-65 (F.C.T.D.), affd. (1987) 3.1 D.L.R. (4th) 584 at 588 , an allegation that the law on patent rights violated either or botl। "liberty" and "security of the person" was rejected; and Parkdale Hotel Ltd. v. A.G. of Canada (1986) 27 D.L.R. (4th) 19 (F.C.T.D.), an allegation that a law restricting the sale o: liquor on election day violated the "liberty" interest was rejected.

28. Re Terzian and Workers Compensation Board (1983) 148 D.L.R. (3d) 380, 42 O.R. (2d) 14 . (Ont. Div. Ct.), a case involving the right to sue for employment related injuries; Aluminun : Co. of Canada Ltd. v. Her Majesty the Queen in the Right of Ontario (1986) 29 D.L.R. (4th ) 583, 55 O.R. (2d) 522 (Ont. Div. Ct.), a case involving the right to market pop cans; $R$. $v$ Video Flicks Ltd. (1984) 48 O.R. (2d) 395 (C.A.); R. v. Quesnel (1985) 24 C.C.C. (3d) 79, 5 ; O.R. (2d) 338 (C.A.); leave to appeal refused 55 O.R. (2d) 543 at 544 (S.C.C.), a cas: involving the issue of the right to work; Manicom v. County of Oxford (1985) 21 D.L.R. (4th । 611 (Ont. Div. Ct.), a case involving a claim of diminishment of the use of property as a resul : of the construction of a landfill site; Re Malartic Hygrade Gold Mines (Canada) Ltd. ane! Ontario Securities Commission (1986) 27 D.L.R. (4th) 112 (Ont. Div. Ct.), a case involvin:: an allegation that a cease trading order was a breach of s. 7; and Mirhadizadel v. The Queel! in the Right of Ontario (1987) 33 D.L.R. (4th) 314 at 316 (Ont. H. Ct.), in which the Cour : found that security of the person relates to physical and mental integrity, not to the right to sue.

29. Aluminum Co. of Canada Ltd. v. Her Majesty the Queen in the Right of Ontario id. D.L.R at 592. See further, Manicom v. County of Oxford id. at 618. 
recently with its decision in $R$. v. Morgentaler, ${ }^{30}$ the Ontario Court of Appeal appears to be widening the breadth of interpretation of s. 7. In that case, it indicated that it would be placing too narrow an interpretation on $\mathrm{s}$. 7 to limit it to protection against arbitrary arrest or detention, and thus certain rights, such as the right to marry, have children, take medical advice and clothe oneself are so fundamental that they can be classed as part of life, liberty and security of the person. The reference to the right to clothe oneself may well be a foundation for future arguments that even if traditional property is not included in s. 7, the "new property" is. The Saskatchewan Court of Appeal has also found that s. 7 does not protect economic rights, ${ }^{31}$ as has the Nova Scotia Court, ${ }^{32}$ the Newfoundland Supreme Court, ${ }^{33}$ and the Manitoba Court of Appeal..$^{34}$

Only one decision in the Yukon, ${ }^{35}$ two decisions in British Columbia and one decision in Alberta have found that 5.7 includes the protection of economic interests. It is important to note that the jurisprudence on the issue is divided in both Alberta and British Columbia.

In Alberta, two decisions of the Court of Queen's Bench found that property rights were not protected by s. $7{ }^{36} \mathrm{~A}$ recent decision of Bracco J. might be considered to contradict this position, however, in the writer's view this is not a necessary conclusion. In Budge v. Workers Compensation Board (Alberta), Number $2,{ }^{37}$ a decision involving the issue of a worker's right to sue a tortfeasor for damages, Bracco J. found that s. 7 was to be

30. (1985) 48 C.R. (3d) 1, 11 O.A.C. 81 (Ont. C.A.).

31. Re Basset and Government of Canada (1987) 35 D.L.R. (4th) 537 at 567 (Sask. C.A.).

32. Re Workers Compensation Board of Nova Scotia and Coastal Rentals Sales and Service Ltd. (1983) 12 D.L.R. (3d) 564 (N.S.S.C.), a case involving the allegation that property interests were breached by provisions in the Workers Compensation Act and Zutphen Brothers Construction Ltd. v. Dydwidag Systems Int. Canada Ltd. (1987) 35 D.L.R. (4th) 433 (N.S.C.A.), a case involving the right to sue the Federal Crown in a court other than the Federal Court.

33. Newfoundland Association of Public Employees v. The Queen in the Right of Newfoundland 85 C.L.L.C. par 14020, 53 N. \& P.E.I.R. 1 (Nfld. S.C.), a case involving the question of whether the right to bargain collectively and to strike is included in s. 7. In Piercey v. General Bakeries Ltd. (1987) 31 D.L.R. (4th) 374 (Nfld. S. Ct.), the limitation on the right to sue under the Workers Compensation Act 1983 was struck down on the basis of s. 15. There was no reference to $\mathrm{s.} 7$.

34. Gershman Produce Co. Ltd. v. Motor Transport Board [1986] 1 W.W.R. 303 (Man. C.A.), a case involving cancellation of a commercial public service certificate; although some of the judges seem to rely on the fact that the license was a right not a privilege, the majority ruled on the matter by finding that $\mathrm{s} .7$ was not intended to protect commercial or economic rights. This decision was considered in Re Francen et al and the City of Winnipeg (1986) 28 D.L.R. 81 at 90 (Man. C.A.), a decision in which the Court observed that the carrying on of every business was not a liberty. In Re Isabey and Manitoba Health Services Commission (1986) 28 D.L.R. 736, [1986] 4 W.W.R. 310, 40 Man. R. (2d) 198 (Man. C.A.), leave to appeal to S.C.C. dismissed October 27, 1986, the Court found that the review of a doctor's billings by the government did not constitute a violation of liberty under $\mathrm{s} .7$.

35. Re Branigan and Yukon Medical Council (1986) 26 D.L.R. (4th) 286 (Y.T.S.C.). A case involving the withdrawal of a doctor's license. The procedures employed by the Medical Council were upheld under $\mathrm{s} .1$.

36. These decisions were Re Budge and Workers Compensation Board [1985] 1 W.W.R. 437 (Alta. Q.B.), a question of the right of suit for damages sustained in the course of employment and Re Becker and the Queen in the Right of Alberta (1983) 148 D.L.R. (3d) 539 (Alta. Q.B.), affd. on other grounds (1983) 148 D.L.R. (3d) 539 (Alta. C.A.), a case involving expropriation of real property.

37. (1987) 80 A.R. 207 (Alta. Q.B.). 
interpreted broadly, and after a review of Supreme Court of Canada interpretations of the Charter, he found that since the plaintiff worker's physical security had been violated by the accident, and the right to sue the tortfeasor was only the enforcement of the right of physical security, the law suit might proceed. Thus, although the decision on its face might appear contrary to other decisions which have found that the right to bring a law suit is not protected by $\mathrm{s} .7,{ }^{38}$ a close reading indicates that it is not. The cause of action in Budge is so closely connected with the right to security of the person, a right that is clearly protected by s. 7, that the Court was able to allow the lawsuit without having to find that 5.7 protected economic rights. The decision is currently under appeal.

In British Columbia a very wide interpretation of liberty was employed by the Court of Appeal in $R$. v. Robson, ${ }^{39}$ when it found that a temporary suspension of a driver's licence is a loss of liberty. However, the Court in that case clearly stated the while "liberty" was not confined to freedom from bodily restriction, it does not include property. ${ }^{\circ 0}$ Despite this, in the decision of Re Mia and Medical Services Commission of B.C., the Robson decision was relied on as authority for the wide meaning to be assigned to liberty, and from there the Court went on to find that the right to work or practice a profession is so fundamental that it must be protected by the $\mathrm{s.} 7$ refrence to liberty. ${ }^{41}$ In another case the Court found that the deprivation of a business licence was protected by s. $7 .^{42} \mathrm{However}$, in seven other cases the Court found that economic interests were not covered.$^{43}$ In one case, the

38. See, for example, Zutphen Brothers Construction Ltd. v. Dydwidag Systems Int. Canada Ltd., supra n. 32 at 438. Even in that decision the Nova Scotia Court of Appeal recognized that the denial of certain causes of action might be contrary to $\mathrm{s} .7$ if the cause of action is so closely connected with a s. 7 right as to be protected.

39. (1985) 19 D.L.R. (4th) 112, confirming (1984) 11 D.L.R. (4th) 727.

40. Id. Neemtz J.A. at 114. Taggart J.A. agreed with Neemtz J.A. Esson J.A., after quoting from American jurisprudence on the wide meaning of "liberty", stated that due regard must be had to differences in wording between the two countries' constitutional documents, attitudes, traditions and history, and then stated that s. 7, unlike the American due process clauses, does not guarantee a right of property.

41. (1985) 17 D.L.R. (4th) 385 at 415-16 (B.C.S.C.). The case involved a doctor who had been refused a billing number by the B.C. Medical Services Commission, and thereby was effectively unable to work. See also, Stoffman v. Vancouver General Hospital (1986) 3C D.L.R. (4th) 700, a case involving hospital privileges to older doctors.

42. Re D\& H Holdings Ltd. and City of Vancouver (1985) 21 D.L.R. (4th) 230.

43. Noves v. Board of School Trustees, School District No. 30 (South Cariboo) (1985) 64 B.C.L.R. 287 (B.C.S.C.), a case involving the right of an employer to suspend without pay a teacher who had been charged, but not yet convicted, of sexual offences with children; Homemade Winecrafts (Canada) Ltd. (1986) 26 D.L.R. (4th) 468 at 471 (B.C.S.C.), a case in which the right to advertise, market and sell a product was claimed to be in the nature of a property right; Bhindi v. B.C. Projectionists (1985) 20 D.L.R. (4th) 386, which involved a closed shop agreement which the applicants claimed violated the freedom of contract. $R_{\epsilon}$ Abbotsford Taxi Ltd. and Motor Carrier Commission (1985) 23 D.L.R. (4th) 36! (B.C.S.C.), a case involving a licence. In Re Grant and Crane Construction Corporation (1986) 28 D.L.R. 606 (B.C.S.C.), a case involving a right to housing, the Court relied on the decision in $R e$ Robson to find that property was not protected under s. 7. The decision in $R_{t}$ Mia was not referred to. In Re Wilson and Medical Services Commission of B.C. (1987) 36 D.L.R. (4th) 31, [1987] 3 W.W.R. 48, 9 B.C.L.R. (2d) 350 (B.C.S.C.), another case involving the assignment of billing numbers to medical practitioners, $R e$ Mia and most of the above mentioned cases plus some unreported British Columbia decisions were reviewed, and the Court found that economic rights were not protected by s. 7. Re R.V.P. Enterprises Ltd. anc Minister of Consumer and Corporate Affairs (1987) 37 D.L.R. (4th) 148 (B.C.S.C.), a cast involving liquor licenses, made a similar finding. 
Court distinguished $\operatorname{Re}$ Mia on the basis that while the "opportunity" to make a living might be protected by s. 7, the "making" of a living was not." It would be fair to say that the weight of British Columbia authority is now opposed to the decision in $\operatorname{Re}$ Mia.

As stated above, to date there has been no definitive statement on this question from the Supreme Court of Canada. In Singh v. Minister of Employment and Immigration ${ }^{45}$ Justice Wilson quoted from American jurisprudence on their notion of liberty, as incorporating more than mere freedom from bodily restraint, but also such concepts as freedom of contract. She also referenced some of the wide range of meanings that could be applied to security of the person, and quoted from s. 25 of the 1948 Universal Declaration of Human Rights on the right to security:

Everyone has the right to a standard of living adequate for the health and well being of himself and of his family, including food, clothing, housing and medical care, and necessary social services, and the right to security in the event of unemployment, sickness, disability, widowhood, old age, or other lack of livelihood in circumstances beyond his control.

However, as it was unnecessary for the purposes of the case to decide the issue, she did not decide whether these definitions were applicable to $\mathrm{s.} 7$ or not. The most recent case where this argument was made before the Supreme Court of Canada is the so called Sunday closing case of $R$. v. Edwards Books and Art Ltd. ${ }^{, 4}$ in which one of the appellants argued that the law requiring him to close his shop on Sunday infringed on his liberty. The Supreme Court again chose not to express an opinion on the limits of the term "liberty". Chief Justice Dickson, speaking for the four justices who expressed any opinion on this point, simply stated that whatever the precise contours of the term were, it did not extend to an unconstrained right to transact business whenever one wishes. ${ }^{47}$ However, he did not expressly say there was no economic component to the term "liberty".

Clearly the question of whether economic rights are protected under s. 7 is at present unanswered. In view of the very limited weight given by the Supreme Court to the debates surrounding the enactment of the Charter, ${ }^{48}$ it is an open question what its interpretation will be. It is possible that the "new property" economic interests such as welfare rights and licences will be included in s. 7 , even if more traditional types of property interests remain excluded. However, until the Supreme Court gives some definitive statement, there will likely continue to be contradictory decisions made by lower courts on this issue.

44. Re Abbotsford Taxi Ltd. and Motor Carrier Commission, id.

45. (1985) 17 D.L.R. (4th) 422 at 460.

46. [1986] 2 S.C.R. 713, (1987) 35 D.L.R. (4th) 6, 30 C.C.C. (3d) 385. In the lower court decision, Tarnopolsky J.A. speaking for the Court of Appeal had expressed the view that "[t]he concept of life, liberty and security of the person would appear to relate to one's physical or mental interests and one's control over these, rather than some right to work whenever one wishes. . . . Being required to close at certain times is not a deprivation." Reported as R. v. Video Flicks Ltd. supra n. 28 at 433.

47. Id. S.C.R. at 785-6. On this point, Justice Beetz joined with Chief Justice Dickson and the two Justices who concurred with Chief Justice Dickson.

48. See the discussion below of Reference Re Section 94(2) of the Motor Vehicle Act R.S.B.C. 1979 c. 288 [1985] 2 S.C.R. 486, (1986) 24 D.L.R. (4th) 536, [1986] 1 W.W.R. 481. All references to this decision will be to the report in the S.C.R. 


\section{THE NATURE OF THE SECTION 7 PROTECTION}

In order to predict the effects of adding property to $\mathrm{s.7}$, it is necessary to review the judicial interpretations to date on the section. Section 7 has become one of the most litigated sections of the Charter and its interpretation has varied considerably over the five years of Charter litigation. The early judicial decisions, and many of the early commentaries, focused on the issue of whether $\mathbf{s .} 7$ allowed for a substantive or simply a procedural review. There was often no attempt to differentiate the concepts of an unlimited substantive review of the content of legislation, and a substantive review of legislation limited to procedural matters. The Supreme Court in Reference Re Section 94(2) of the Motor Vehicle Act R.S.B.C., 1979, c. $288^{48 A}$ has now given an extensive opinion on s. 7 , and has indicated a path which may make many of these early decisions and legal commentaries of little relevance. ${ }^{49}$ This opinion has been further clarified by the recent Supreme Court decision in Morgentaler v. The Queen. ${ }^{30}$

It is apparent that the judicial interpretation of $s .7$ endorsed by the Supreme Court in the Motor Vehicle Act Reference case is far different than what was anticipated by the drafters of the Charter. It also differs from the interpretations suggested by most legal commentators, many of whom made their comments without the benefit of any judicial decisions. Although there are more indications today of the meaning that is to be assigned to s. 7, there are still unanswered questions. Even where apparently definitive answere have been given, it is quite possible that current minority interpretations will, one day, achieve the same status of Justice Laskin's dissent in Murdoch v. Murdoch, ${ }^{\text {s1 }}$ and become the law of

48A. Supra n. 48.

49. Most of the earlier cases had found that s. 7 only gave procedural protection, relying directly or indirectly on the testimony of the legislative draftspeople that "fundamental justice" should be interpreted to mean "natural justice" and, therefore, only made legislation inoperative to the extent that it violated procedural fairness rules. $R$. v. Holman 28 C.R. (3d) 378 (B.C. Prov. Ct.); Re Jamieson and the Queen (1982) 70 C.C.C. (2d) 430 (Que. C.S.); $R e$ Mason; Mason v. the Queen 43 O.R. (2d) 321, 35 C.R. (3d) 393 (Ont. H. Ct.); Re M.H. and R. (1984) 17 C.C.C. (3d) 433, [1985] 2 W.W.R. 444 (Alta. Q.B.); Clark v. Clark (1982) 40 O.R. 383 (Ont. Co. Ct.); Queen v. Hayden (1983) 3 D.L.R. (4th) 361 (Man. C.A.), leave to appeal to S.C. refused, Dec., 1983, 26 Man. R. (2d) 318n; Re Potma and the Queen (1983) 2 C.C.C. (3d) 383 (Ont. C.A.), later interpreted by the Ont. C.A. as not intending to say that s. 7 was limited to procedural review. The more recent cases began to find that $\mathrm{s} .7$ provided for a substantive review. In R. v. Stevens (1983) 3 C.C.C. (3d) 198 (Ont. C.A.), leave to appeal to the Supreme Court granted June 6, 1983, the Court assumed without deciding the issue that the Charter allowed the Court to review the substance of the legislation. See also, $R$. v. Young (1984) 40 C.R. (3d) 289, 13 C.C.C. (3d) 1 (Ont. C.A.); R. v. Roche 46 C.R. (3d) 160, 20 C.C.C. (3d) 524 (Ont. C.A.); R.L. Crain Inc. v. Couture (1983) 10 C.C.C. (3d) 119 (Sask. Q.B.); Reference Re Section 94(2) of the Motor Vehicle Act, R.S.B.C. 1979 c. 288 (1982) 42 B.C.L.R. 364, (1983) 19 M.V.R. 63 (B.C.C.A.); R. v. Morgentaler (1985) 48 C.R. (3d) 1, 11 O.A.C. 81 (Ont. C.A.). It is interesting to note that the Supreme Court judgment in Motor Vehicle Act Reference was in the end very similar to the interpretation urged by Manning, supra n. 18 at 227-274 who not only argued that fundamental justice included substantive rights, but also advanced the two right theory of interpretation to s. 7 which seems to have found favour with Wilson J. Others had argued more tentatively for these interpretations, but Mr. Manning also advanced a number of arguments in support of his contentions that were subsequently used by individual members of the Supreme Court.

50. [1988] 1 S.C.R. 30, (1988) 44 D.L.R. (4th) 385.

S1. [1975] 1 S.C.R. 423, [1974] 1 W.W.R. 361. 
the land. For this reason, before embarking on a discussion of the meaning of s. 7, it is well to keep in mind the following quote from Allan Gold in his discussion paper on the Charter, written prior to the commencement of Charter litigation: ${ }^{52}$

Conclusions are rare; only suggestions and tentative opinions abound. Undoubtedly, the new Charter will be what judges decide to make of it. The American Bill of Rights found no quarrel with racial discrimination for a century. . . . The nature and extent of the Canadian judiciary's response to the challenge of the Charter's legal rights provisions will be less a matter of content and more a matter of context and, ultimately, judicial conscience.

\section{A. THE NATURE OF THE SECTION 7 REVIEW PROCESS}

The Supreme Court decision in the Motor Vehicle Act Reference case established a number of rules of procedure for s. 7 litigation. All the Justices agreed that for the section to have any application, there was a threshold test to be met. Unless there has been a deprivation of life, liberty or security of the person, the section does not apply. The Court found that the "principles of fundamental justice" are not rights in themselves, but qualifiers of the right not to be deprived of life, liberty and security of the person. ${ }^{33}$

The next issue dealt with was what is the nature of the s. 7 review, a question which itself depends on the nature of the rights protected. Are these rights of which a person can only be deprived in accordance with the principles of fundamental justice, and only then when such a deprivation can be demonstrably justified in accordance with s. 1 of the Charter (in other words, the deprivation must be fair and justifiable); or are the s. 7 rights only qualified rights which can be taken away at any time provided that the deprivation is in accordance with the principles of fundamental justice; or, if not in accordance with fundamental justice, provided that the failure to follow those principles is reasonably justified under s. 1 (in other words, the deprivation need only be fair or justifiable)?

The majority view, as espoused by Lamer $J$., favoured the latter interpretation. Once a deprivation of one of the protected rights in contravention to the principles of fundamental justice is proven (it is not clear whether a litigant must simply prove the deprivation, and then the burden shifts to the government to prove that the deprivation is in accordance with fundamental justice, or if the litigant must establish both the deprivation, and that prima facie the deprivation is contrary to the principles of fundamental justice), the court considers whether the deprivation of rights in contravention to the rules of fundamental justice is saved by s. 1. Thus, Lamer J. in giving the decision for the majority, first found that s. 94(2) of the B.C. Motor Vehicle Act offended s. 7 of the Charter, and then asked the question whether the appellants had demonstrated that the section was salvaged by the operation of s. 1 of the Charter. ${ }^{\text {s4 }}$

52. Gold, "The Legal Rights Provision - A New Vision or Deja Vu" 4 Sup. Ct. L. Rev. 107.

53. Supra $\mathrm{n} . \mathbf{4 8}$ at $\mathbf{5 1 2}$ and 523.

54. Id. at 519. 
Wilson J., in her decision, disagreed with the majority that s. 1 could save a deprivation of a protected right that was contrary to principles of fundamental justice. She found that a limit of a s. 7 right in violation of the principles of fundamental justice automatically violated the Charter since she felt that a limit on one of the enumerated rights in this manner could not be either "reasonable" or "demonstrably justified in a free and democratic society". This suggestion, although contrary to the majority opinion, has been expressed before in previous judicial decisions ${ }^{35}$ and in doctrinal contributions. ${ }^{56}$ However, in her judgment in Morgentaler v. The Queen, ${ }^{57}$ Wilson J. followed the majority view and after finding that s. 251 of the Criminal Code violated the principles of fundamental justice went on to consider whether the section might be saved by the operation of s. 1 of the Charter.

In the next part of her judgment in the Motor Vehicle Act Reference case, Wilson J. considered what would be the effect of a deprivation of a fundamental right, absent a breach of fundamental justice. Clearly this amounts only to dicta, and Lamer J. expressly refrained from offering a view as to what would be the effect of $\mathrm{s} .7$ in these circumstances. Madam Justice Wilson stated that even if the deprivation of a s. 7 right is in accordance with fundamental justice, the matter does not end there, for she held that it still must be justified under s. 1 . To Wilson J. the requirement in s. 7 that the principles of fundamental justice be observed was simply a restriction on the legislature's power to impose limits on the s. 7 right under s. 1: she ackowledges that there is a right to limit the s. 7 freedoms under s. 1, and indicates that the explicit wording of s. 7 means that it can only be exercised in accordance with the principles of fundamental justice. The result is that a deprivation of liberty could be in accordance with the principles of fundamental justice, but would nevertheless be a violation of the Charter as an unreasonable limit under s. 1. It should be noted that this view was implicitly rejected by both Chief Justice Dickson and Beetz J. in their judgments in Morgentaler v. The Queen. Dickson C.J. expressly stated that Parliament had the right to infringe on the security of the person in any way that it wished, provided that it did so in a manner consistent with the principles of fundamental justice..$^{58}$ However, their remarks were obiter as both found that there had been a violation of the principles of fundamental justice.

The view expressed by Wilson J. is a restatement in clearer terms of the so called "two right" theory of s. 7 which was based on a strict grammatical reading of the section - that there is a right to life, liberty, and security of the person which is only limited by the reasonable limits test in s. 1 , and secondly that there is a right not to be deprived of life, liberty, and security of the person except in accordance with the principles of fundamental

55. For example, the decision of Finch J. in R. v. Robson (1984) 11 D.L.R. (4th) 727. The B.C. Court of Appeal ultimately disagreed with him on the point.

56. Whyte, supra $\mathrm{n} .18$ at $\mathbf{4 6 5}$; Bender, "Justification for Limiting Constitutionally Guaranteed Rights and Freedoms" (1983) Man. L.J. 669 at 676-79.

57. Supra n. SO S.C.R. at 180.

58. Id. at 63-72 and 110-111. 
justice. ${ }^{99}$ Wilson J. had raised this issue in Operation Dismantle v. The Queen, ${ }^{60}$ and then declined to deal with it. Apparently, she now felt the time was appropriate.

The interpretation endorsed by Wilson $\mathrm{J}$. has been described as leading to the fullest substantive review possible, ${ }^{61}$ and if it is later accepted as the proper approach, and property rights are imported into s. 7 through legislative or judicial amendment, it could result in a deprivation of property, for example by expropriation without adequate compensation, being found valid as in accordance with fundamental justice, but then being held invalid because it did not accord with a general standard of social justice imported by the court into $\mathrm{s.} 7$ through s. 1. Furthermore, it gives credence to the argument discussed below that $s$. 7 is not only a negative right which protects against deprivation of rights, but also gives positive protection to these rights, and therefore, for example, could be the basis for law suits against the government asserting a right to social programs to protect the security of the person.

Left unresolved by the decision is the question of what is included in the term "principles of fundamental justice"? We now know that these principles have substantive content, but what is the exact content of these standards of fairness, and what are the safeguards that will be in place to ensure that the fairness rules do not become the modern day equivalent to the "Chancellor's foot". This topic will be discussed in the next section of this article.

The Motor Vehicle Act Reference decision is both a beginning and an end. It represents a beginning of a new debate on what substantive principles are part of the fundamental public order of Canada, and what is the yardstick to determine whether any deprivation which violates the fundamental freedoms can be upheld under s. 1; and at the same time the decision represents an end to a long debate over whether there could even be reference to substantive law in considering whether a state action violated the principles of fundamental justice, and if there could, was the court limited to defining the principles of fundamental justice (that is, the substantive law) as only procedural principles. Before reflecting on the new challenges that are raised by this decision, it is useful to examine the controversies it has closed off.

Initially, a number of judges and legal writers defined as the important question in assessing the effect of s. 7 , the issue of the nature of the judicial review that was to be carried out by the court. Was it a procedural review only, with the court limited to determining whether the executive had correctly and fairly followed the procedure set out in the law, or could it also be a substantive review under which the court could consider the question of the content of the law? Professor Tremblay in a recent article, ${ }^{62}$

59. This two right theory was advanced by, inter alia, Hogg, supra $\mathrm{n} .11$ at 743 , and Manning, supra $\mathrm{n} .18$ at 231.

60. [1985] 1 S.C.R. 441, at 491 .

61. Hogg, supra n. 11 at 744. White, Annotation to Reference re S. 94(2) of the B.C. Motor Vehicle Act 48 C.R. (3d) 293 at 295.

62. Tremblay, "Section 7 of the Charter" (1984) 18 U.B.C. Law Rev. 201. 
made it clear that this was the wrong question. As he pointed out, the nature of the judicial review is determined by the constitutional law of the country, and traditionally in Canada, as in the United States, but not in England with its unitary system of government and its doctrine of parliamentary sovereignty, our courts have looked at the content of laws to determine if they have been validly passed (that is, were they within the competence of that particular level of government to pass the law). Moreover, he points out that the differences between substantive review or "substantive due process" and "procedural due process", American terms which were often imported into the debate, are not clearly defined in either Canadian jurisprudence or doctrine. Also, he mentions that definitions of substantive review, which identified it as a review of the content of legislation to determine if the legislation met certain substantive standards, and procedural review, as simply a determination of whether the executive had acted with fairness in carrying out the law, were inadequate. ${ }^{63}$ More and more, it was coming to be recognized that procedural and substantive review were not two separate concepts, but part of the same continuum of review. ${ }^{64}$

Professor Tremblay suggested that the discussion should shift from the nature of the review process to its scope. The question would be whether the court, in reviewing the content of the law, could only consider procedural provisions, or could it also review the substantive content of the law. However, the focus for him remained the difference between substantive and procedural content of laws. One of the positive aspects of the Motor Vehicle Act Reference is that the focus is no longer on this question, but simply on the content of the principles of fundamental justice without any necessity to define a principle as having a substantive or procedural content.

Lamer J., in his opinion for the majority in the Motor Vehicle Act Reference, pointed out that the use of the substantive/procedural dichotomy narrows the issue, and pre-empts an open-minded approach to determining the meaning of "principles of fundamental justice". He suggested, with some merit, that the debate "is largely bound up in the American experience ... [and] imports into the Canadian context American concepts, terminology and jurisprudence, all of which are inextricably linked to problems concerning the nature and legitimacy of adjudication under the U.S. Constitituion . . . [which] it must be remembered, has no s. 52 nor has it the internal checks and balances of ss. 1 and 33". ${ }^{65} \mathrm{He}$ added, that to simply "allow the American debate to define the issue for us" will do our own Constitution a disservice because of the

63. Id. at 202-207. Professor Tremblay illustrates how both executive and legislative acts can have a procedural and substantive dimension.

64. See, for example Mackay, "Fairness after the Charter" [1985] Queens L.J. 263 at 272 and 292. A good example of this continuum, is the case of Roncarelli v. Duplessis [1959] S.C.R. 121 , in which a substantive act of the executive was declared invalid because it was not according to law, that is, it violated the rule of law that every act of the executive must be authorized. In the United States, Professor Tremblay has shown that procedural review enables the courts to review not only the acts of the executive, but the legislation establishing the procedures.

65. Supra n. 48 at 498. 
fundamental structural differences between our Constitution and that of the United States.

Why had the question focused in on this issue of procedural or substantive review in considering the nature and/or scope of the judicial review process as it relates to s. 7? Clearly, it was related to the American experience in constitutional litigation involving the two due process clauses in its Bill of Rights, the Fifth and Fourteenth Amendments, the former which prohibits the federal government, and the latter the state governments, from depriving a person of life, liberty, or property in violation of due process of law. These clauses established the model for s. 1(a) of the Canadian Bill of Rights on which s. 7 of the Charter was largely based. And it was a desire to try to either invoke, or more usually to exclude, the American substantive due process precedents in Canadian constitutional litigation that caused the debate to focus in the manner that it did, both in litigation under s. 1(a) of the Canadian Bill of Rights, in the choice of language by the drafters of s. 7, and for the last five years, in litigation under s. 7.

As the Supreme Court stated in Motor Vehicle Act Reference, these concepts are not relevant to our constitutional debate. There are several reasons for this. Lamer J. referred to structural differences between our Constitution, and that of the United States. These structural differences between our constitutions are analyzed by Professor Tremblay as part of his detailed review of the basis for substantive and procedural review in the American constitutional cases. He points out that this right of substantive review preceded the enactment of the "due process" amendments, and was then based on the founding notion of the American Constitution: that the ordinary citizens of the country had certain inalienable rights with which no state could interfere. As part of the "social compact" to form a government, certain powers were given to government, but these "natural rights" were protected from state action, first by this implicit philosophical limitation found within the Constitution itself, and later by explicit expression in the Amendments to the Constitution. ${ }^{60}$

The Canadian Constitution is not based on this theory that some laws are beyond the power of the legislators, and subject to a repudiation of the views of Beetz J. in Dupond v. The Queen, ${ }^{67}$ no aspect of lawmaking is considered beyond a properly constituted legislative body acting within the powers assigned to it under ss. 91 or 92 of the Constitution Act, 1867. In other words in Canada, as in England, there is the concept of Parliamentary sovereignty, subject only to the possibility of an implied Bill of Rights. Unlike England, under our federal system of government, our courts have had to look at the content of the legislation to determine whether it was intra vires the legislature which had passed the law. However, this was quite different than the testing of legislation by substantive standards which

66. Supra n. 62 at 214-216. Long before the enactment of the Fourteenth Amendment in 1868, Professor Tremblay points out that the American Supreme Court would strike down a state statute which violated the higher natural law by interfering with the right to property or to liberty. See, Wilkinson v. Leland 27 U.S. (2 Pet) 627 (1829), and Fletcher v. Peck 10 U.S. (6 Cranch) 87 (1810).

67. (1978) 84 D.L.R. (3d) 420. 
occurred in the United States. Even the Charter cannot import the principle of inalienable rights upon which the American Constitution was based, nor take away from our law the principle that all legislative powers had been exhaustively distributed between the two levels of government. Finally, it is clear that although s. 7 might on its own be thought to create a class of subjects on which neither level of government can legislate, when one considers ss. 1 and 33, such a conclusion becomes untenable, for under either section laws violating fundamental justice could be enacted.

The U.S. Supreme Court defined its role in constitutional cases to include the right to review not only the way in which a law had been carried out by the executive, but also the substantive content of the law itself, for the court had to determine whether it was within the power of the state to enact the measure under review, or whether it was part of the inalienable rights of the ordinary citizens under the social compact theory of government. Later when that theory fell into disuse, the courts would consider whether it was one of the fundamental rights guaranteed under the Fifth, and later, the Fourteenth amendments. Thus, in the late nineteenth and early twentieth centuries the American courts would strictly scrutinize any enactment interfering with property rights (which under the social compact theory was a matter reserved to the ordianry citizen, and later was explicitly protected by the due process guarantees of the Fifth and Fourteenth amendments) or with the right to contract (which was considered as part of property or the liberty interest) and unless it had a substantial relation to the protection of the public health, morals or safety of the state, the so called police powers, the enactment would be held invalid.

It is apparent from some of these decisions that the free enterprise majority of the U.S. Supreme Court simply disagreed with the increased government regulation of the economy, and moved against any legislation that they saw as progressive and redistributive social and economic legislation. However, the tests that were employed to determine validity were extremely subjective: thus, the courts had to consider the necessity of the measure, its appropriateness, and even its reasonableness, and reasonableness was in the view of the Court. During this period of time, the U.S. Supreme Court used this power of review to strike down laws in the following areas: labour legislation, price regulation and trade and business practice. Thus, laws establishing maximum hours of work, ${ }^{68}$ minimum wages ${ }^{69}$ and collective bargaining rights ${ }^{70}$ were declared invalid on the basis that such laws were an unreasonable interference with liberty, and/or property, two concepts which the courts usually did not bother to distinguish.

But by the 1930's, the U.S. Supreme Court had changed its attitude towards the application of substantive due process principles to economic

68. Locknerv. New York 198 U.S. 578 (1904). Interestingly enough the Supreme Court sustained legislation regulating hours of work for women within three years of this case, based on the special needs of women: Muller v. Oregon 208 U.S. 412 (1907). A few years later, legislation regulating hours of work for men was also upheld: Bunting v. Oregon 243 U.S. 426 (1916).

69. Adkins v. Children's Hospital 261 U.S. 525 (1922); Murphy v. Sardell, 269 U.S. 530 (1925).

70. Coppage v. Kansas 236 U.S. 1 (1914). 
and social legislation, and, thereafter, applied a new test which, while not giving up the right to substantively review the content of legislation, would not strike down such legislation dealing with economic matters where there was an evil at hand for correction, and the questioned measure might be thought of as a rational way to correct it. A presumption of validity was applied, and the wisdom of the law was no longer reviewed unless it was demonstrably arbitrary or irrational." Thereafter, many of the old decisions arising from substantive review of laws encroaching on property rights were overruled.

The right to review the substance of legislation however, remained, but was now only applied when a "fundamental freedom", such as a right concerning religion, expression and assembly, the right to fairness in the criminal process, the right to vote or the right to privacy, as opposed to a property right, was encroached upon. Thus the U.S. Supreme Court invoked "substantive due process" in the area of privacy to strike down laws regarding contraceptives, ${ }^{2}$ abortion, ${ }^{3}$ and procreation. ${ }^{74}$ There is no presumption of validity with respect to laws involving a fundamental freedom, and the law must be found necessary to promote a compelling and overriding interest of government before it will be found to be valid. Even if it could have had a narrower scope it will be held to be invalid. ${ }^{75}$ While technically, the existence of the doctrine of substantive due process means that even now, a U.S. Supreme Court with a new economic philosophy could again begin to strike down government regulatory laws which interfere with the property rights of private Americans by applying substantive due process principles, it appears that this is unlikely to happen. ${ }^{76}$ However, whether this situation repeats itself in the United States or not, substantive due process is not relevant to our jurisprudence because the foundation of the doctrine is not the use of particular language in the due process amendments, but the nature of the American Constitution.

Not only is this American jurisprudence irrelevant because its legal foundation is fundamentally different than ours, but in addition, our legal tradition is quite different. Before the enactment of the Canadian Bill of Rights and the Charter, our courts followed the English concept of "due process of law" which because of the doctrine of parliamentary sovereignty prevented any review of legislative action (other than to ensure that the law was intra vires the level of government that had passed the law): the only requirement was that the act of the executive be according to law, that

71. West Coast Hotel v. Parrish 300 U.S. 379 (1936). Tremblay, supra n. 62 at 224.

72. Griswold v. Connecticut 410 U.S. 113 (1972) (extending the right to married couples); Eisenstadt v. Baird 405 U.S. 438 (1971) (extending the right to unmarried persons); Carey v. Population Services International 431 U.S. 678 (1976) (extending the right to minors).

73. Roe v. Wade 381 U.S. 479 (1964).

74. Cleveland Board of Education v. LaFleur 414 U.S. 632 (1973).

75. Tremblay, supra n. 62 at 225.

76. In Ferguson v. Skrupa 372 U.S. 726 at 731 (1962), Justice Black stated: "We refuse to sit as a 'superlegislature to weigh the wisdom of legislation', and we emphatically refuse to go back to the time when the Courts used the Due Process Clause to 'strike down laws, regulatory of business and industrial conditions, because they may be unwise, improvident, or out of harmony with a particular school of thought'.... Whether the legislature takes for its textbook Adam Smith, Herbert Spencer, Lord Keynes or some other is no concern of ours." 
is, in accordance with the authorizing legislation of Parliament. ${ }^{n}$ With the enactment of the Canadian Bill of Rights, we had in s. 1(a), a counterpart to the Fifth and Fourteenth Amendments including the phrase "due process of law", but this again was interpreted in the tradition of our previous "due process" rules. This simply allowed a review of the substantive content of legislation in so far as it dealt with procedure.$^{78}$ This was the equivalent to the American procedural due process: the court was not limited to a review of the way in which the executive carried out the legislation, but might, if necessary, review the procedural content of the law to see if it is in accordance with principles of fairness. An even more conservative approach was advocated by some who interpreted s.1(a) as authority only to review the way in which the executive had carried out the law. In any event, clearly substantive due process as defined in the United States was not part of our legal tradition.

When considering the enactment of the Charter, the Canadian legislators clearly wanted to avoid a re-enactment of the extremes that had accompanied early American substantive review of the content of legislation. For this reason, the original draft of s. 7 presented by the federal government at the Federal-Provincial Constitutional talks during the summer of 1980 which contained the phrase "due process" was criticized by some of the provinces, who voiced fears of the courts reviewing the ethical propriety of legislation. ${ }^{79}$ Accordingly, the federal government redrafted s. 7 for the September 1980 First Minister's Conference, to both delete "property" as a protected right, and substitute for "due process" (the term which had been taken from the Canadian Bill of Rights) the little known concept of "fundamental justice". ${ }^{80}$

It is this draft that eventually was enacted. While some have suggested that due process was dropped because of a wish to avoid the narrow procedural interpretation that the Supreme Court had given to the "due process" term in the Canadian Bill of Rights, in fact the testimony of those responsible for drafting s. 7, makes it clear that they thought that by using the term "principles of fundamental justice" they were in effect adopting

77. Tremblay, supra n. 62 at 205.

78. Tremblay, supra n. 62 at 211. Although it is arguable that Laskin C.J. appeared to recognize in both his decisions in Curr v. The Queen [1972] S.C.R. 889 at 898 , and Miller v. The Queen [1977] 2 S.C.R. 680 at 688, that judicial review could extend to the substance of the legislation, and that substance could possibly extend past procedural content, because of the doctrine of parliamentary supremacy, and the fact that the Canadian Bill of Rights was only a statutory document, a fact that he mentioned several times, he stated in Curr (at 898) that compelling reasons would have to be advanced before the Court would deny operative effect to an otherwise duly enacted piece of legislation and enter the "bog of legislative policymaking". In Miller he was somewhat clearer when he stated that a measure such as a mandatory death penalty for theft would be offensive to s. 2(d) because the harshness of the penalty would of fend social and moral standards of decency. However, the cautious language used by Laskin C.J. in Curr has often been interpreted as a rejection of even the possibility of substantive review of non-procedural matters, at least under a statutory bill of rights. See also, Morgentaler v. The Queen [1976] 1 S.C.R. 616.

79. Whyte, supra n. 18 at 456.

80. Federal-Provincial Conference of First Ministers on the Constitution, Revised Discussion Draft: The Canadian Charter of Rights and Freedoms (Sept. 8-12, 1980), Canadian Intergovernmental Conference Secretariat Document 830-84/004. 
the limited procedural effect that had been given to that phrase in litigation under s. 2(e) of the Canadian Bill of Rights, that is, that the phrase was synonymous with "natural justice", and had no substantive content whatsoever. ${ }^{81}$ This is no more clearly set out than in the following two excerpts from the evidence of Dr. B.L. Strayer, then Assistant Deputy Minister, Public Law: ${ }^{22}$

Mr. Chairman, it was our belief that the words "fundamental justice" would cover the same thing as what is called procedural due process, that is the meaning of due process in relation to requiring fair procedure. However, it in our view does not cover the concept of what is called substantive due process, which would impose substantive requirements as to policy of the law in question. This has been most clearly demonstrated in the United States in the area of property, but also in other areas such as the right to life. The term due process has been given the broader concept of meaning both the procedure and substance. Natural justice or fundamental justice in our view does not go beyond the procedural requirements of fairness.

Mr. Crombie: "Natural justice and fundamental justice do not deal with substantive matters, only procedural fairness, that is the difference between those two and due process?"

Mr. Strayer: "Yes"

In the Motor Vehicle Act Reference the Supreme Court has confirmed the trend in lower court decisions and found that not only was a substantive review of the content of the legislation permissible under the Charter, such a review was not limited to procedural content. This was effected by the Supreme Court giving a content to the principles of fundamental justice beyond the traditional notion of natural justice. ${ }^{83}$ It made this finding after specifically accepting as admissible the minutes of the Joint Committee on the Constitution, and in fact specifically considered most of the passage quoted in this article. But although the Court found the testimony admissible, it felt that little weight should be assigned to it. However, the Court clearly rejected the American jurisprudence in coming to its conclusion, neither invoking the basis for the American decisions, nor using any of the tests employed by the Supreme Court when reviewing laws involving economic rights or fundamental freedoms.

81. In the decision of Duke v. The Queen [1972] S.C.R. 917 at 923, Fauteux, C.J. stated that "Without attempting to formulate any final definition of those words [principles of fundamental justice], I would take them to mean, generally, that the tribunal which adjudicates upon his rights must act fairly, in good faith, without bias and in judicial temper, and must give to him the opportunity adequately to state his case." What was ignored by those relying on these words of Fauteux C.J. was that the phrase "principles of fundamental justice" in s. 2(e) was placed in the context of a guarantee of a fair hearing, and it would be inconceivable if anything other than a guarantee of procedural fairness was intended.

82. Minutes of the Proceedings and Evidence of the Special Joint Committee, 46:32, 46:42; also, 46:33-36, and the evidence of the Minister of Justice, the Hon J. Chretien, 46:43 (January 27, 1981).

83. Prior to this decision, many legal commentators had speculated that 5.7 might well be the basis for a substantive review of legislation, but at least one, had considered that the substantive content might come by giving a procedural effect to the last clause with its reference to "fundamental justice", and interpreting the first clause as imposing substantive limits on government deprivation of life, liberty and security of the person. See, Bender, "The Canadian Charter of Rights and Freedoms and the United States Bill of Rights: A Comparison" (1983) 28 McGill L.J. 811 at 825. As the Supreme Court was unanimous in its view of fundamental justice, this theory at least can be put to rest. 
[VOL. XXVI, NO. 3

\section{B. THE PRINCIPLES OF FUNDAMENTAL JUSTICE}

The most important question remaining to answer, in order to establish the potential effects of entrenching property rights in $\mathrm{s}$. 7 , is what principles of law are contained in the term "principles of fundamental justice"? The Supreme Court has established in its decision in the Motor Vehicle Act Reference, that this term includes both principles of procedural fairness, that is, of natural justice, and also principles of law with a substantive content. This means that the law itself which authorized the deprivation of the s. 7 protected right, and not just the procedure set up in the law, must satisfy substantive principles of fairness. However, the Court has only stated in general that some of the principles of fundamental fairness are substantive, and has left it to future litigation to further define what these principles are.

What have we learned specifically about the principles of fundamental justice from this decision, which upheld lower court decisions invalidating s. 94 of the B.C. Motor Vehicle Act, a section which created an absolute liability offence of driving a motor vehicle with a suspended licence, the penalty of which was a mandatory jail sentence? The Supreme Court was clear that the principles of fundamental justice went beyond the principles of natural justice, for it was felt that to define the principles of fundamental justice so narrowly would be to increase the possibility of depriving individuals of the protected rights, and would strip s. 7 of most of its content since many of the principles of natural justice are already incorporated into ss. 8 to 14 . These sections were held to be illustrative only of the wider principles incorporated in $\mathrm{s.} 7$ (Wilson J. disagreed on this point, feeling that ss. 8-14 stood alone, and were not relevant in interpreting s. 7). Both Lamer and Wilson JJ. agreed that if the legislators had truly wanted the principles of natural justice to be synonymous with the term "natural justice", that term of art should have been used. Jurisprudence under the Bill of Rights was also considered, but felt to be of little use because of the fact that interpretation of the Canadian Bill of Rights was founded on different principles because it was only a statutory document, and s. 2(e) of the Bill of Rights was irrelevant because it placed the words "principles of fundamental justice" in the context only of a "right to a fair hearing" rather than in the context of a qualifier to much more fundamental rights.

The Supreme Court found that the principles of fundamental justice were to be found in the presumptions of the common law and in the international conventions on human rights. It was said that all have been recognized as essential elements of a system for the administration of justice, which is founded on a belief of "the dignity and worth of the human person ... and on the rule of law": The Court attempted to establish these principles as standards that have long been recognized by our legal system, as opposed to principles from the realm of general public policy. However, it did not further define which principles were part of these fundamental principles, other than to say that "[w] principle may be said to be a principle of fundamental justice within the meaning of $\mathrm{s} .7$ will rest upon an analysis of the nature, sources, rationale and essential role of the principle within the judicial process and in our 
legal system as it evolves." ${ }^{84}$ The only principle of fundamental justice that actually emerged from the decision was the requirement of mens rea, ${ }^{85}$ for any offence with the possibility of penal sanctions.

It is the definition of the content of the fundamental principles of justice which is now the most important task for the courts in s. 7 litigation. This was recognized in an earlier Saskatchewan Queen's Bench decision by Scheibel J. who, after finding that $\mathrm{s} .7$ did indeed contemplate a review of the substantive content of the legislation, stated that::86

The more fundamental question is what yardstick is suggested by the phrase "principles of fundamental justice" against which the validity of substantive legislation can be measured?

After reviewing the jurisprudence he added:

Several themes recur in these cases that are possible yardsticks for reviewing substantive legislation. These are: the historical development or rights protected by the common law, the legislative tradition in Canada as found in an analogous existing legislation and community standards or the "living tradition". There is also reference to the need for compelling factors to justify placing the collective interests of society ahead of the rights of the individual.

These statements may further help in the task of defining the principles of fundamental justice.

Defining the principles of fundamental justice will be a process which will take many years. Most of these principles already exist in our legal system, but it is clear from the words of Mr. Justice Lamer, quoted above, that to some extent they will be evolved by the courts, with the judiciary at liberty to find and create new principles of fundamental justice where it appears necessary. What of the existing principles of law that may be part of these fundamental principles? Clearly, the procedural concepts inherent in the phrase "natural justice" are included. In their judgments in Morgentaler v. The Queen, both Chief Justice Dickson and Justice Beetz relied on procedural rather than substantive principles of fundamental justice to find that the therapeutic abortion provisions of the Criminal Code deprived Canadian women of the right not to have their security of person taken away except by the rules of fundamental justice. Dickson C.J. relied on the ambiguity of the term "health" as well as the principle that a defence to a criminal charge (here undergoing or performing an abortion) must be real and not, as in the case of abortion, in practice illusory. Moreover, he made a finding that the system regulating abortion was manifestly unfair and found that administrative unfairness constituted a violation of the principles of procedural fundamental justice. ${ }^{87}$ Beet $\mathrm{J}$. disagreed with the finding that the failure to define health violated the principles of fundamental justice, but did agree that the delays inherent in the administrative structure in the system for obtaining abortions,

84. Supra n. 48 at 513 . Manning, supra n. 18 at 264 who advocated this same approach whereby the judiciary will fashion by a case by case analysis of these principles, also at 255-264 has an interesting discussion of some sources that the courts could look to in finding and developing these principles.

85. See, for example, R. v. Beaver [1957] S.C.R. 531 which recognized this principle of fundamental justice in Canadian criminal law.

86. R.L. Crain Inc. v. Couture (1984) 10 C.C.C. (3d) 119 at 149 and 151 (Sask. Q.B.).

87. Supra n. 50, at 63-70. 
particularly the need for abortions to be performed in accredited or approved hospitals, created unnecessary delays which resulted in manifest unfairness. The Morgentaler decision indicates the vagueness inherent even in procedural principles of fundamental justice, and the scope for creative justice.

Even less is known of the content of the substantive principles. The Supreme Court made reference to the presumptions of the common law. These presumptions were discussed by Professor Tremblay who described a number, the two broadest being one, that a statute contrary to the reason of the common law would be void, ${ }^{88}$ and two, the sacredness of the right to liberty and property (a presumption which he acknowledges cannot be constitutionally entrenched unless property is incorporated into s. 7). Other presumptions listed included presumptions against retrospective operation, substantial alteration of the law, interference with vested rights, injustice, unreasonableness or absurdity, impairing obligations, ousting established jurisdictions, and against creating new or enlarging existing jurisdictions. ${ }^{89}$ Professor Tremblay traced the evolution of these principles as they changed over time from fundamental law which posibly could not be assailed even by Parliament (similar to the inalienable rights of citizens in the American Constitution), ${ }^{90}$ to simple principles of statutory construction where the intention of Parliament was ambiguous, principles which gave way to the supremacy of parliament, but only in the face of a direct and unequivocal enactment. In the absence of such express words, statutes would be applied subject to them. ${ }^{91}$

Although these presumptions were at one time subject to the rule of the supremacy of parliament, Parliament, subject to a s. 33 override, is now subject to the Charter. Accordingly, some, or all, of these presumptions of law, may some day be characterized as "fundamental principles of justice", and as constitutional principles become the fundamental law that they once were thought to be, although these principles of law will only have operative effect if the threshold test of a deprivation of a protected right in 5.7 is met. We do not of course know if all the common law presumptions would be incorporated into the principles of fundamental justice. However, we do know that some of these presumptions are very far

88. Tremblay cites as authority for this proposition the statement of Lord Coke in Dr. Bonham's case (1610) 8 Co. 114a (C.P.): "When an act of parliament is against common right or reason, or repugnant or impossible to be performed, the common law will control it and adjudge such act to be void". This statement is put in context in Gough, Fundamental Law in English Constitutional History (1961) at 30-40. Modern authorities relying on this statement as a principle of statutory interpretation are: Artermiou v. Procopiou [1966] 1 Q.B. 878, (Eng. C.A.) at 888 wherein it was stated that "An intention to produce an unreasonable result is not to be imputed to a statute if there is some other construction available"; Luke v. I.R.C. [1963] A.C. 557 (H.L.) at 577; and A.G. v. Prince Augustus of Hanover [1957] A.C. 436 (H.L.).

89. Tremblay, supra n. 62 at 248-249.

90. There is some dispute as to how "fundamental" these principles ever were, with some arguing that they were always subject to being overruled by Parliament. See, Gough, supra n. 88 at 5 6.

91. Tremblay, supra n. 62 at 239-443. Tremblay relies in part for his authorities on this point on Gough, id., who seems to ground some of these presumptions in principles of natural law, and Keir and Lawson, Cases in Constitutional Law (4th ed. 1967), who suggest that others were developed by the courts to do "justice and equity". 
reaching, particularly the presumption against an unreasonable law, which as Professor Tremblay points out, brings to mind the concept of reasonable law developed in the United States under the doctrine of substantive due process. ${ }^{92}$

In Morgentaler only Wilson $\mathrm{J}$. included substantive content in the principles of fundamental justice that she relied upon to strike down the abortion law. She found that a women's right to liberty included the right to decide for herself whether she would continue her pregnancy, ${ }^{93}$ and that a women's right to security of the person includes the right to be protected against psychological trauma and interference with her physical well being. ${ }^{94}$ She found that the deprivation of these rights not only violated the principles of procedural justice as found by Dickson C.J. and Beetz J., but also violated the substantive right to freedom of conscience and religion. She found that this and other rights found elsewhere in the Charter must now be considered as principles of fundamental justice. Her judgment finds that any law prohibiting abortion at a time when the state interest in protecting a foetus is not paramount (she leaves this timing decision to the legislators but appears to feel it might become paramount at some time in the middle of the second trimester of pregnancy) should be struck down as contravening a substantive principle of fundamental justice.

The important information that we now have from this decision of Wilson $\mathrm{J}$. is that in addition to the common law principles of fundamental justice described by Professor Tremblay, we now have to look to the Charter itself for the source of further substantive principles. Thus for example, a law which violates aboriginal rights might be reviewable under s. 7 if the law also interferes with one of the protected s. 7 rights.

While it does not necessarily follow that once the courts take the view that the Charter allows for substantive review of the non-procedural content of laws, that the courts will be lead inexorably to question the wisdom of enactments and to adjudicate upon the merits of public policy, one can state that if a s. 7 review was limited to the narrow procedural review that the legislative draftspeople thought they were authorizing, there would be no foundation for those fears..$^{95}$ To be fair, the judicial decisions in which the courts have gone beyond a procedural to a substantive review of the government action, have often contained avowals that the courts do not intend to commence a frequent questioning of the merits or wisdom of enactments, and that they have no intention of

92. The concept of unreasonableness has received a number of interpretations over the years from the courts, and most indicate that it is not to be mistaken for wrongful or mistaken, but for a situation in which in the circumstance prevailing no reasonable person could have so acted. See, Secretary of State for Education and Science v. Tameside Metropolitan Borough Council, [1977] A.C. 1014, Lord Denning at 1025-26, and Lord Scarman at 1032. Deschenes, C.J. relied on Lord Denning's judgment in Quebec Association of Protestant School Boards v. A.G. of Quebec, (1983) 140 D.L.R. (3d) 33, in the context of s. 1 of the Charter, and Lord Scarman's definition was relied on in Bell v. The Queen [1979] 2 S.C.R. 212 at 223.

93. Supra n. 50 at 171-172.

94. Supra n. 50 at 173-174.

95. There have been a number of good discussions on the arguments for and against substantive review. It is not intended to summarize them here, and reference should be made to Whyte, supra n. 18 at 469-472, and Mackay, supra n. 64 at 295-302. 
becoming the unelected "super legislature" beyond the reach of legislatures, a result to which some fear substantive review of legislation will inevitably lead. ${ }^{96}$ After the decision in Morgentaler v. The Queen many people are questioning those statements. However, it was the governments which gave to the judiciary the role of supervising laws in accordance with the Charter, and the judiciary take the position that they cannot now put a strained interpretation on the Charter to avoid a substantive review of nonprocedural content.

The Supreme Court could have characterized the substance of the Charter violation in Motor Vehicle Act Reference as procedural in nature, and it may be that later courts will take that view in order to narrow the scope of Charter review. However, that results in a return to the difficult question of what acts are procedural, and what substantive, which as indicated above, is a question to which no clear answers are available. The Supreme Court has taken the view that the task of the judiciary must be to secure for persons the "full benefit of the Charter's protection", ${ }^{7}$ while avoiding adjudication of the merits of public policy. In the Motor Vehicle Act Reference the Court indicated this may not be accomplished by simply choosing to limit the review to procedural content. Certainly, if the legislators choose to create a mandatory death penalty for jaywalking, can there be any question that the protection of the right to life entrenched in s. 7 can only be secured by a substantive review of the content of the legislation.$^{98}$ To limit a review in those circumstances to a determination of whether there had been a fair hearing would be clearly useless to the hapless jaywalker.

An alternative limit that has been suggested that might be imposed by the courts on themselves, is to limit the right to review the substantive content of legislation involving the administration of justice. ${ }^{99}$ Thus, the content of the principles of fundamental justice would be limited to those principles essential for determining legal liability and the consequences of such determination (for example, is the punishment cruel and unusual). Limiting the scope of the principles of fundamental justice to matters related to the administration of justice would have the effect of precluding the kind of substantive review of economic and social legislation which some fear might occur in the future, fears that will be explored in the next section of this article.

96. See the judgment of Lamer J. in the Motor Vehicle Act Reference, supra n. 48 at 497-499. Also, R. v. Morgentaler, Smoling and Scott 48 C.R. (3d) 1 (Ont. C.A.) at 39 wherein it was stated that substantive reivew should not take place "except in exceptional circumstances where there has been a marked departure from the norm of civil and criminal liability, resulting in the infringement of liberty or some other injustice. The policy and wisdom of legislation should remain first and foremost a matter for Parliament and the legislature:"

97. Dickson J. (as he then was) in R. v. Big M Drug Mart Ltd. [1985] 1 S.C.R. 295 at 344, quoted with approval by Lamer J. in Motor Vehicle Act Reference supra n. 48 at 499.

98. This of course is the extreme example. However, in less extreme cases the courts both in Canada and the U.S. have undertaken a substantive review of legislation and struck down laws. The case under discussion, Motor Vehicle Act Reference is a case in point. Here an absolute liability offence with a mandatory jail term was declared invalid. An American example is found in the case of Griswold v. Connecticut 410 U.S. 113 (1972).

99. White, supra n. 61 at 293. Support for this proposition is the statement of Lamer J. supra n. 48 at 503 that the principles of fundamental justice are those that have been recognized as essential elements of a system for the administration of justice. 


\section{LAWS THAT MAY FACE CHARTER CHALLENGES IF PROPERTY RIGHTS ARE ENTRENCHED}

Much of the above discussion has been oriented to the actual judicial interpretation of $\mathrm{s.} 7$ to date. Using as a basis this interpretation of $\mathrm{s}$. 7, this section of the article will discuss what could happen to laws in a number of different areas if they were challenged under the Charter. It should be emphasized that these are only theoretical possibilities: in the first part of this section a "worst case" scenario (from the point of view of average Canadians, not the large property owners) applied to a number of areas of law will be discussed, and in the second part, a "best case" scenario applied to the protection of the "new property" will be dealt with.

Why should there be a discussion extending to possibilities rather than limited to probabilities? When the Supreme Court established that 5.7 does indeed allow the use of substantive principles of fairness to review the substantive content of challenged legislation, the door was clearly opened to the process which saw American courts disallow legislation because it did not accord with the political views of the majority of the Supreme Court. But any conclusions that any Canadian court will venture through that open door are premature to say the least. At present, it is not even clear what the substantive standards incorporated in the principles of fundamental justice will be. Nor is there a clear indication at this time that the Canadian courts will abandon their traditional judicial restraint and attempt to become a super legislature by examining the wisdom of legislation. Our legal and political history argue against any such judicial activism, and our Constitution is different from that of the United States. Moreover, the presence of s. 1, as a committee of the Ontario section of the Canadian Bar Association pointed out in its report, ${ }^{100}$ may well establish the kind of reasonable limit on substantive review that the U.S. Supreme Court imposed on itself after 1937. The Canadian Bar committee, reporting prior to the Supreme Court decision in the Motor Vehicle Act Reference, concluded that "no existing governmental scheme would be prevented or seriously impeded" by the entrenchment of property in s. 7 . At the same time, it appears that few members of that committee would likely have forseen that our abortion laws would be struck down as a violation of the Charter.

The "worst case" scenario still deserves exploration. While these are only theoretical possibilities that might occur if property rights become entrenched in s. 7, the question must be asked, why run the risk? Do the benefits of entrenchment of property rights in 5.7 outweigh the risks now that we know that s. 7 is not merely a procedural protection? The answer must be a clear no.

There are numerous laws which could be the subject of constitutional challenges as to their substantive validity, if property rights are entrenched in s. 7. What follows is an exploration of six of the most commonly identified laws which might be at risk. ${ }^{101}$

100. A summation of parts of that brief is contained in the British Columbia Paper on property rights in the Constitution, supra n. 14.

101. See, for example, an article in the Law Union Newsletter in October 1983 by Reuben Hasson. 
[VOL. XXVI, NO. 3

\section{A. LANDLORD AND TENANT}

In 1981 the Irish Supreme Court, relying on the constitutional guarantee of property that existed in Article 40 of the Constitution of Ireland, 1937, struck down rent control legislation that had been in existence in various statutory forms since $1915 . .^{102}$ At the same time provisions which were regarded as integral to the rent control scheme such as limits on the ability of landlords to obtain possession of rent controlled premises were also struck out, despite the voiced concern of the Court of the effect this would potentially have on tens of thousands of tenants. The main provision regarding the entrenchment of property rights in the Irish Constitution, Article 43, contained explicit recognition that the exercise of the rights to property must be regulated by "the principles of social justice", and accordingly "the State may on occasion delimit by law the exercise of the said rights with a view to reconciling their exercise with the exigencies of the common good". However, the Court acted under Article 40 which was headed "personal rights", and which had a requirement that the State shall in the case of "injustice done ... vindicate the property rights of every citizen". The Court refused to accept arguments that all references to property rights elsewhere in the Constitution were subject to the limitations found in Article 43.

Would that happen to Canadian landlord and tenant laws? Even those landlord and tenant laws without an aspect of rent control clearly encroach on the enjoyment of property rights, and so there is a deprivation under $\mathrm{s}$. 7. Whether that deprivation is in violation of any fundamental principle of justice awaits a fuller exposition of the substantive content of these principles, whether for example, the presumption of the common law suggested by Professor Tremblay as to the sacredness of private property, will be considered to be a fundamental principle of justice. Definitive answers also await further indications from the Court as to the criteria to be used in assessing whether a deprivation in violation of fundamental justice will be allowed to stand under s. 1 , as a justifiable measure in a free and democratic society.

\section{B. ENVIRONMENTAL LEGISLATION}

Laws requiring anti-pollution measures to be taken again clearly encroach on the rights of property owners to freely enjoy their property. For example, the requirement that the owner of an open pit mine clean up the land could be considered a deprivation of property. ${ }^{103}$ Again, before such a law was invalidated under the Charter there would have to be a finding that such a deprivation was in violation of a fundamental principle

102. Blake v. The Attorney General [1982] I.R. 117 (Irish S.C.).

103. In East Coast Lumber Terminal v. Town of Babylon 174 F. 2d. 106 (1949), that was the issue in an application by a sand and gravel pit owner for an injunction. Although the temporary injunction was refused, the matter was considered to be a proper matter for trial, with the issue being framed on the basis of whether the requirements were so burdensome as to be a deprivation of property, the test being whether the requirements were in the zone of what reasonable people think is reasonable, not on the basis that the court should substitute its own discretion. 
of justice, and if there were such a finding, that the impairment was not saved by s. 1 . If, on the other hand, Madam Justice Wilson's minority views in the Motor Vehicle Act Reference ever become a majority view, the deprivation would have to not only satisfy the s. 7 test of being in conformance with the principles of fundamental justice, but also a test under s. 1, that the deprivation itself, even if in conformity with the principles of fundamental justice, was justifiable in a democratic society.

It seems unlikely that any court would not uphold such legislation under either or both tests, but it could depend in the future on the political wisdom of the Supreme Court as to the reasonableness and justness of the legislation. This is certainly the present American situation. It is recognized that all restrictions on the use and enjoyment of property by environmental protection or zoning laws are not unconstitutional. However, for the law to be considered valid, the burden and cost of the environmental law, or the diminuition of value in the case of zoning laws, must be reasonable, and not in the court's view amount to confiscation. If it is not considered reasonable, it will be held to be unconstitutional as a contravention of the constitutional protection of property rights. Again, restrictions on property which were not tolerated fifty years ago, are now more likely to be sustained. However, the court reviews the substantive content of the legislation, not just the procedures set out in the laws, and in a number of cases, some of recent origin, has declared laws restricting the use to which property might be put to, or laws regulating that use, as unconstitutional. ${ }^{104}$

\section{LABOUR LAW}

It was in the field of labour legislation that the U.S. Supreme Court, in the heyday of substantive due process applied to social and distributive legislation, made such an indelible mark on the memories of progressive legislators both in the United States and Canada. The Canadian labour laws of today are more far reaching than the American maximum hours and minimum wage laws which were then overturned. Some laws which clearly would encroach on the enjoyment of property and/or the freedom to contract would be legislation forbidding the use of strike-breakers during a strike, legislation requiring companies to justify plant closures, occupational health laws, and equal pay laws, particularly those incorporating the idea of equal pay for work of equal value. While it may be thought that these laws are all easily justifiable in a democratic society, and that we should ignore what happened in the United States, in another era when less far reaching laws were declared invalid as irrelevant to the constitution and culture, we should remember, that even though the same strict scrutiny is not applied to American economic laws as was once applied, as late as 1978 , routine factory inspections were held to be unconstitutional in the United States. ${ }^{105}$

Again what will happen in Canada will depend on the content that is inserted into the principles of fundamental justice and the attitudes of the courts.

104. There are a number of such cases. See, 16A Am. Jur. 2d S. 397-99, and 82 Am. Jur. 2 d. S. 13.

105. Marshall v. Barlow's Inc. 98A S. Ct. 1816 (1978). 
[VOL. XXVI, NO. 3

\section{NATIONALIZATION}

If at some future time a provincial or federal government decides to nationalize an industry, several issues will arise. First, even with a "fair" compensation, and compliance with the principles of fundamental justice, if Madam Justice Wilson's test were to be applied, the government would have to justify the nationalization under s. 1 . What tests would a court require the government to meet to justify the nationalization? Moreover, if the courts take it upon themselves to review the compensation, and find it inadequate in their view, there will be questions of whether fundamental fairness principles are being violated. Yet a requirement that the "market value" be the basis for compensation, may make the nationalization impracticable, as could the imposition of prompt compensation. The court's decisions in matters such as these, which may touch the heart of a government's political program, yet possibly form a violation of strongly held political philosophies among the judiciary, have all the ingredients for future political controversies, unless the government gives the courts the easy way out, and uses the s. 33 override when bringing in the nationalization program. Unfortunately for the courts, s. 33 overrides have already proven so unpopular politically that their use will be very sparing.

\section{E. TAXATION}

Would the imposition of wealth taxes and death duties, particularly the former, be acceptable to the judiciary, or would they be characterized as a form of confiscation, and, therefore, a violation of a principle of fundamental fairness? Again, this question rides on the issues of what are the principles of fundamental justice, and what standards will be applied in establishing s. 1 limits. A limitation of the content of these principles to matters relating to the administration of justice would mean that the substance of the legislation would not be subject to review.

\section{F. MATRIMONIAL PROPERTY LAWS}

In all provinces except Quebec there are provisions for a distribution of marital property on separation or divorce, and in all provinces, including Quebec, provisions to allow a court to grant exclusive possession of the matrimonial home to one spouse on separation. These provisions clearly result in a deprivation of property to the spouse who owns the most property. It was the fear that matrimonial property laws would be subject to attack under s. 7 that led the Canadian Advisory Council on the Status of Women to take a position in opposition to the entrenchment of property rights in the Charter. These fears have been communicated successfully to the politicians, and the majority of speeches by elected politicians on this subject, in and out of the legislature, now refer to this potential problem, and contain assurances that if property rights are to be entrenched, they will be done so in such a way as to protect these hard won rights.

For there to be a successful challenge to a law under the Charter there must be some state action. In the American context it is quite clear that government enforcement of private claims to property by one person against another is a deprivation of property which invokes the application 
of the due process clause. ${ }^{106}$ In Canada the Supreme Court has ruled that a court order by itself does not constitute state action. ${ }^{107}$ However, where that court order is based on a statutory instrument (as opposed to the common law), even in litigation between two private individuals where no government agency is directly involved, the Charter can be invoked. ${ }^{108}$ Thus, a spouse who is ordered to turn over half of his farm or half of his pension should be able to use a Charter argument to challenge the validity of the legislation under s. 7.

But how successful would such a challenge be? In the United States, despite the existence of the due process clauses, it has generally been considered that matrimonial support laws and matrimonial property laws providing for the division of matrimonial assets, while they may amount to a deprivation of property, are valid exercises of the governmental interest in maintaining social institutions as part of the larger governmental concern for the protection of its citizens. ${ }^{109}$ Since our courts to date have in general been very supportive of these types of laws, and in particular, have interpreted them in a remedial way, for the most part giving effect to the principles of sharing, equality and equity in such laws, it appears likely that in this area at least, even an entrenched property right in s. 7 would be unable to invalidate these laws. The public interest in such laws would no doubt be given effect in any application by reference to s. 1, if resort was needed to that section because such laws were found to violate some principle of fundamental justice.

This is not to say that the inclusion of property in $\mathrm{s.} 7$ will have no effect on Canadian spouses. It is quite likely that there will be challenges until there have been some definitive decisions on $\mathrm{s.} 7$ and matrimonial support and property division legislation. While the remote possibility exists of a tremendous change in judicial attitudes in this area, which would result in a change in successful Charter challenges to matrimonial property laws, this is very unlikely in the writer's view. Accordingly it is predicted that such litigation will be fruitless to all except the lawyers involved, and will simply have the effect of depriving both spouses of more of their property as a result of the costs of litigation.

106. Snaidach v. Family Finance Corp. 395 U.S. 337 (1968), a case involving the use of a prejudgment garnishee by the respondent.

107. Retail, Wholesale and Department Store Union Local 580 v. Dolphin Delivery Ltd., [1986] 2 S.C.R. 573 at 600 .

108. Id. at 603, Mr. Justice McIntyre in coming to this conclusion, pointed to the case of $R e$ Blainey and Ontario Hockey Association (1986) 26 D.L.R. (4th) 728, as an example of a case where the Charter had been applied to invalidate a statute in private litigation. Any Act of the legislature that specifically authorizes or directs an abridgement of a guaranteed right removes the matter from the private sphere of action where the Charter does not apply. See further, Christian, "Section 7 and Administrative Law" (1987) 3 Administrative L.J. 25 at 26.

109. Beckton, "Re: Entrenchment of Property Rights in the Canadian Charter of Rights and Freedoms", an unpublished paper prepared for the Canadian Advisory Council on the Status of Women, 1983, at 28. The paper is available at the Publications Centre of the C.A.C.S.W. Office in Ottawa, Ontario. The case of Hays v. Hays $124 \mathrm{Jo} .2 \mathrm{~d} 917$ (La. S. Ct.) (1960) is an example where the Court found against a husband who argued that the state's alimony laws amounted to an unlawful taking of his property on the basis that the law was validly passed in the public interest. 


\section{G. THE EXTENT OF THE "WORST CASE" SCENARIO}

The six areas singled out above, are not intended to be exhaustive. The number of laws that could be attacked if property rights were entrenched in s. 7 is limited only by the imagination of lawyers. For example, other areas which might be affected in this "worst case" scenario are the control of pornography (where the distributors might allege anti-pornography laws are an interference with their right to enjoy property); debt-relief laws such as those providing for the consolidation and repayment of debts at lowered interest rates, or laws preventing foreclosures of family farms; finally, as a number of the provinces and representatives of the New Democratic party indicated in the Committee Hearings on the Constitution, land utilization laws, such as zoning regulations and foreign ownership regulations might be ruled invalid.

It is recognized that this is only a partial list of potential problems, one intended merely to illustrate the point of the inherent dangers of property entrenched in the Charter in such a way that the substance of the legislation is measured by substantive criteria developed by the courts on the nebulous theme of fairness. No doubt it appears that the concerns regarding many of the laws singled are exaggerated and unwarranted. This is certainly the view of the British Columbia government in dealing with these issues, and as has been indicated, is the conclusion reached by the Canadian Bar Association. But then that was likely the attitude of the Irish lawyers when they first heard of the proposed challenge to their rent control legislation.

\section{H. POSITIVE ASPECTS OF THE ENTRENCHMENT OF PROPERTY: PROTECTION OF THE “NEW PROPERTY"}

To this point in this article, only the "worst case" scenarios have been explored. It has been argued by some that the entrenchment of property rights may have a positive side for those who do not own traditional forms of property, but are reliant on some part of the more modern form of wealth, that being some form of government largesse, such as social welfare benefits, government contracts, franchises or jobs, or on the obtaining of an occupational license to carry on a profession. Charles Reich described this new type of wealth as the "new property","10 arguing that for most people their ability to earn a living formed the bulk of their wealth, and a very important component of this wealth was the "new property" made up of government entitlements which not only provide a living, but also form the basis for status in our society, and as such should be accorded legal protection. We will now examine the "best case" scenario to see whether the entrenchment of property rights has the potential to give that type of protection.

Assuming first that the Charter is amended legislatively, what would the effect be on those claimants to the "new property"? Everything will of course depend on the definition of property, for if property includes only traditional types of property, such as tangible assets like real property, chattels and traditionally recognized rights such as stocks and debentures,

110. Reich, "The New Property" (1964) 73 Yale Law Journal 733. 
there would be no benefits to those who do not own these types of "old property".

Reich would define a benefit as property on the basis of the importance of the benefit to the individual in conjunction with a consideration of whether its loss would be grievous. In the United States, Reich's concept of the "new property" has received some limited judicial recognition, and certainly some of the American due process decisions incorporate into the "old" concept of property what some had traditionally classified as privileges. "' However, in later cases there was a retreat from the use of Reich's criteria, and although there is still legal protection accorded to some forms of "new property", the criteria for defining property has changed. Property there can now best be described as "a broad range of interests that are secured by existing rules or understandings that secure certain benefits and that support claims of entitlement to those benefits". 112 The American judicial position with regards to these new property interests can be summarized as follows. While the government is not required to give a benefit such as welfare or public housing, if it does distribute these benefits, it must do so in accordance with constitutional principles, which require procedural fairness principles to be followed. Thus, once a system has been established which creates a claim for entitlement for an individual, then the due process clause will apply. A claim for entitlement arises if the law establishes the criteria for continued receipt of benefits, and the individual appears to meet the criteria. If in fact the law creates no claim to future payments, then an individual has no claim. There is no distinction between privileges and rights. ${ }^{13}$

Whether our courts will adopt such a wide definition of property is not clear, although it is clear that the old distinction between privileges and rights is no longer considered important. ${ }^{14}$ Moreover, without formulating any overall test, already Canadian courts in matrimonial property cases have found that pension rights are a form of property, ${ }^{115}$ and as indicated above in section $\mathrm{I}(\mathrm{C})$ of this article, many of the cases involving economic interests that have been litigated under s. 7 have involved "new property"

111. In Graham v. Richardson 403 U.S. 365 (1970), the S.C. ruled that the due process clauses would henceforth apply to the "new" property of government benefits whether the benefits were characterized as a "right" or a "privilege". Shortly before that clear statement, in Goldberg v. Kelly 397 U.S. 254 (1969), a claim to welfare benefits was granted due process protection, using the criteria that had been suggested by Reich of the importance of the benefit to the individual and whether the loss of the benefit would be grievous.

112. Board of Regents v. Roth 408 U.S. 564 at 577 (1971) and Perry v. Sinderman 408 U.S. 593 (1971). Both cases involved non-tenured university professors who claimed to have been unfairly dismissed.

113. Beckton, supra n. 109 at 18.

114. The majority in the Manitoba Court of Appeal appeared to say that there should be no distinction between privileges and rights, although in either case they felt that there was no s. 7 protection, as it was felt that neither economic rights nor privileges were included in the terms liberty or security of the person. See, Gershman Produce Co. Ltd., supra n. 34. However, the Supreme Court dealt with this quite explicitly in Singh v. Minister of Employment and Immigration supra n. 45 at 461 , although unfortunately not all the justices gave an opinion on the question. Wilson J., speaking for herself and two others, stated that the dichotomy between privileges and rights is no longer acceptable or relevant in litigation under the Charter.

115. See, for example, Herchuk v. Herchuk 35 R.F.L. (2d) 327, [1983] 6 W.W.R. 474 (Alta. C.A.). 
interests which the courts appear to have classified as property, and then either allowed the claim on the basis that $s .7$ covered property rights, or denied it on the basis that it did not.

Accordingly, the "best case" scenario would optimistically say that the "new property" would receive Charter protection if property rights were legislatively incorporated into s. 7 , even if property is not defined in the new amendment.

Even without the legislative entrenchment of property rights in s. 7, as indicated in section $\mathrm{I}(\mathrm{C})$ of this article, it is possible that at some future date the Canadian courts will, by judicial amendment, allow some, or all, forms of economic activity s. 7 protection. This would be done by giving the terms "liberty" and "security of the person" the wide meanings that those terms have received in the United States courts (as regards liberty), and in international law (as regards security of the person). The latter term particularly has the potential to protect the "new property" rights. In view of the fact that the discussions surrounding the exclusion of property rights from s. 7 centered only on traditional forms of property, it may well be more justifiable to judicially incorporate the "new property" economic interests into s. 7, while still honouring the legislative history of the section by excluding traditional property interests.

Moreover, some very respected commentators such as Dean Bender, have referred to the grammatical construction of $s .7$ to suggest that the first clause of $\mathrm{s.} 7$ establishes affirmative rights to life, liberty and security of the person, not simply protection from being deprived of them. ${ }^{116}$ If this were found to be the case, an individual would have the right to demand governmental assistance in maintaining the necessities of life that are incorporated in the broad meaning of "security of the person". However, at the present time the requirement of the Supreme Court, that for s. 7 to become operative there must first be a deprivation, appears to be an obstacle to this interpretation.

Attaining some form of constitutional protection to forms of "new property" would indeed be a worthwhile result for ordinary Canadians. However, attaining it without risking the losses that substantive review of economic measures involving traditional property, would be the most desirable end.

\section{A POSSIBLE COMPROMISE}

In view of the fact that property and civil rights is a matter of strictly provincial concern under s. 92(13) of the B.N.A. Act, it is difficult to justify any reference to property in the Charter. As indicated above, this is one of the major reasons why some provinces, in particular Alberta, oppose the addition of property rights to the Charter. If despite this, the provinces and federal government in the future make some kind of compromise, and decide to entrench property rights in the Charter, then in view of the potential minefield of problems associated with including property rights in 5.7 , some other placement should be considered.

116. Bender, “Commentary" (1983) 13 Man. L.J. 489 at 491 ; Bender, "The Canadian Charter of Rights and Freedoms and the United States Bill of Rights: A Comparison (1983) 28 McGill L.J. 811 at 825-26. See also, Christian, supra n. 19 at 227-228. 
My proposal would be to place property rights into a new section in the Charter which would make it clear that these property rights were only to be protected by principles of procedural fairness. This would be accomplished by using the term of art, "procedural fairness". It is understood that this does not prevent review of the substance of any challenged legislation, but it does limit the ambit of that review to procedural matters only.

It is interesting to note that this was the original plan of the federal government. In the Constitutional Amendment Bill introduced into Parliament in June 1978, clause 6 included, inter alia, "the right of the individual to life, liberty and security of his or her person and the right not to be deprived thereof except by due process of law", but "the right of the individual to the use and enjoyment of property, and the right not to be deprived thereof except in accordance with law"."17 Thus two different tests were established, one including substantive protection, and the other limited to procedural protection. It also appears from the position paper of the government of Prince Edward Island to be a solution which they might endorse.

It is quite possible that if property interests are judicially or legislatively incorporated into s. 7, the courts, as in the United States, might on their own develop a different standard of fairness where a deprivation of an economic interest is alleged. Thus certain rights would be considered more fundamental than others, and economic rights would be protected from deprivation only by procedural safeguards such as a right to a hearing. But if that is what is desired, and particularly if a legislative amendment is going to be made anyway, it appears best to establish the two tests clearly in the legislation.

Such an amendment would have the effect of satisfying those people who feel a need to give property rights constitutional protection. Moreover, if property rights are kept out of s. 7 , the courts are more likely to give a broad interpretation to the principles of fundamental justice which will then have the effect of enhancing the protection granted to life, liberty and security of the person, for the more rights which are protected, the more likely there would be a watering down of the protection granted them..$^{118}$ Finally, in view of the provisions of s. 33, if some provinces still remained opposed to such an amendment, they could take advantage of the right to opt out of the operation of the new clause.

As it has often been said: "Compromise is the Canadian way of life".

117. Manning, supra n. 18 at 258.

118. This argument made by Bender supra n. 116 at 492 has much merit. It may be for example, that limiting the principles of fundamental justice to principles dealing with the administration of justice will result in some injustice going unremedied in the future. Yet, if property rights of any kind are included in 5.7 that is what one must hope will be the judicial limit. 